\title{
Midlatitude Forcing Mechanisms for Glacier Mass Balance Investigated Using General Circulation Models
}

\author{
B. K. REICHERT* AND L. BENGTSSON \\ Max Planck Institute for Meteorology, Hamburg, Germany \\ J. OeRlemans \\ Institute for Marine and Atmospheric Research Utrecht, Utrecht, Netherlands
}

(Manuscript received 27 September 2000, in final form 1 March 2001)

\begin{abstract}
A process-oriented modeling approach is applied in order to simulate glacier mass balance for individual glaciers using statistically downscaled general circulation models (GCMs). Glacier-specific seasonal sensitivity characteristics based on a mass balance model of intermediate complexity are used to simulate mass balances of Nigardsbreen (Norway) and Rhonegletscher (Switzerland). Simulations using reanalyses (ECMWF) for the period 1979-93 are in good agreement with in situ mass balance measurements for Nigardsbreen. The method is applied to multicentury integrations of coupled (ECHAM4/OPYC) and mixed-layer (ECHAM4/MLO) GCMs excluding external forcing. A high correlation between decadal variations in the North Atlantic oscillation (NAO) and mass balance of the glaciers is found. The dominant factor for this relationship is the strong impact of winter precipitation associated with the NAO. A high NAO phase means enhanced (reduced) winter precipitation for Nigardsbreen (Rhonegletscher), typically leading to a higher (lower) than normal annual mass balance. This mechanism, entirely due to internal variations in the climate system, can explain observed strong positive mass balances for Nigardsbreen and other maritime Norwegian glaciers within the period 1980-95. It can also partly be responsible for recent strong negative mass balances of Alpine glaciers.
\end{abstract}

\section{Introduction}

Observed (or reconstructed) glacier fluctuations provide important information on natural climate variability and are also key elements for the early detection of climate change and possible anthropogenic impacts on climate. They result from changes in the mass and energy balance at the earth's surface and therefore represent valuable climatic proxy data. Because of the typical properties of a melting ice or snow surface, glaciers represent highly sensitive climate indicators. The glacierization of the well-documented European Alps, for example, has lost roughly $30 \%-40 \%$ in surface area and about $50 \%$ of its original volume since the middle of the nineteenth century, the end of the so-called "Little Ice Age." Since 1980 alone, a remarkable loss of 10\%$20 \%$ of the remaining ice volume has been observed (Haeberli and Beniston 1998).

\footnotetext{
* Current affiliation: Lamont-Doherty Earth Observatory, Columbia University, Palisades, New York.

Corresponding author address: Dr. Bernhard K. Reichert, LamontDoherty Earth Observatory, Columbia University, 61 Route 9W, Palisades, NY 10964.

E-mail: reichert@1deo.columbia.edu
}

Changes in glacier mass balance (defined as the annual mass gain or loss at the surface; Paterson 1994) can be viewed as the direct, undelayed reaction of a glacier to climatic variations, whereas variations in glacier length are the indirect, delayed, filtered, and strongly enhanced response. Cumulative glacier mass changes lead to changes in ice thickness that then influence the dynamic redistribution of mass by glacier flow (Haeberli 1995). Monitoring glacier mass balance is therefore a direct way to reconstruct climatic variations. However, the available mass balance records are relatively short (usually less than $50 \mathrm{yr}$ ) when compared with relatively long records of glacier length (e.g., the record of Untere Grindelwaldgletscher, Switzerland, begins in 1534).

General circulation models (GCMs) can be used in order to investigate the behavior of glaciers under specific climatic conditions. Natural glacier fluctuations exclusively due to internal variations in the climate system can be simulated. A major advantage of using GCMs is having the opportunity to investigate underlying physical mechanisms responsible for glacier fluctuations inherent to the climate system. If desired, specific external forcings such as, for example, changing greenhouse gas concentrations, can be included.

In this study, we propose a process-oriented modeling 
approach for the simulation of mass balance of individual glaciers using downscaled GCMs. We concentrate on using GCM control integrations excluding external forcings. The important aspect of long-term temperature trends resulting, for example, from solar irradiation changes or greenhouse gas forcing can, however, be addressed in follow-up studies. The approach has two main characteristic features.

First, we simulate the mass balance of individual glaciers using a process-based and glacier-specific mass balance model. We apply glacier-specific seasonal sensitivity characteristics calculated from a mass balance model of intermediate complexity. Although several attempts have been made to use one equation to describe a large number of glaciers or even all glaciers on earth (e.g., Sutherland 1984; Oerlemans 1989; Wigley and Raper 1993), the response of individual glaciers to a climatic signal can vary enormously because of their different geometries or their location in different climatic regimes, leading to entirely different energy-balance characteristics. Climate sensitivity may generally vary at least over one order of magnitude for single glaciers, depending to a large extent on precipitation (Oerlemans and Fortuin 1992). We therefore concentrate on individual glaciers; nevertheless, they will to some extent be representative for glaciers with comparable characteristic features in the same region.

Second, we apply a statistical downscaling approach in order to obtain local conditions from GCM output. Glacier volume has been calculated using regional temperature patterns from the direct coarse gridpoint output of a GCM (Gregory and Oerlemans 1998) in which the impact of precipitation has not been considered. However, climate sensitivity of glaciers depends on local temperature and precipitation. The direct use of coarse GCM grid points (typical resolution, e.g., about $2.8^{\circ} \times$ $2.8^{\circ}$ ) naturally results in a poor representation of the local climate, especially for precipitation, which is highly dependent on local orographic conditions. In this study, both temperature as well as precipitation are therefore downscaled (section 2) using daily European Centre for Medium-Range Weather Forecasts (ECMWF) reanalyses (Gibson et al. 1997) and local station data. Downscaled temperature and precipitation are then used as input for the mass balance modeling approach (section 3).

For validation of the entire approach including downscaling and mass balance modeling, we simulate glacier mass balance directly using ECMWF reanalyses for comparison with in situ mass balance measurements (section 4). This is an important basis for the application of the method to various GCM experiments (section 5). The process-oriented modeling approach is particularly interesting since it enables us to investigate forcing mechanisms for glacier mass gain or loss of individual glaciers. As an example, the relationship between the North Atlantic oscillation (NAO) and the behavior of specific European glaciers will be investigated for the glaciers Nigardsbreen (Norway) and Rhonegletscher (Switzerland) considering the individual seasonal impact of temperature and precipitation (section 6). On the basis of the obtained results, we will furthermore discuss the recent development of observed glacier mass balances, including the observed strong positive mass balances of Nigardsbreen during recent decades (section 7).

\section{Statistical downscaling approach}

A comparison of three methods of downscaling $(\mathrm{Cu}-$ basch et al. 1996) shows that direct interpolation of GCM grid points to a local site results in a poor representation of the local climate and that statistical downscaling is an appropriate and inexpensive tool for regions with sufficient observational data to train the model.

\section{a. Method}

The statistical downscaling approach used in the present study is based on daily operational weather station data in the vicinity of the glacier sites to be investigated and on an extensive set of potential daily large-scale predictors obtained from ECMWF reanalyses. The ECMWF reanalyses consist of a validated and reasonably consistent global dataset of assimilated data for the period 1979-93 (Gibson et al. 1997). Robust statistical relationships between the large-scale flow obtained from reanalyses and local variables are developed in order to be applied to the output of the European Centre/Hamburg (ECHAM) GCM experiments.

A detailed description of the downscaling approach (including model validation, investigation of the role of near-surface predictors, spatial homogeneity of the model, seasonal-specific relationships, the impact of spatiotemporal resolution of predictors, etc.) can be found in Reichert et al. (1999). In the following, the performance of the statistical model for the areas of interest in this study will be briefly described.

\section{b. Downscaling for Rhonegletscher}

Rhonegletscher is a temperate valley glacier located in the Swiss Alps $\left(46^{\circ} 37^{\prime} \mathrm{N}, 8^{\circ} 24^{\prime} \mathrm{E}\right)$. Its altitudinal range is $2140-3620 \mathrm{~m}$; the total area covered by the glacier is $17 \mathrm{~km}^{2}$ (Hoelzle and Haeberli 1999). Figure 1 shows the locations of Rhonegletscher and the 24 operational weather stations used for statistical downscaling (stations 13, 14, 04, 18, and 02 are not used since the available records did not cover the complete period of the ECMWF reanalyses).

The explained variances (EVs) of the statistical downscaling model with respect to observed local temperature and observed local precipitation have been calculated for individual stations in the area of investigation. For this calculation, monthly averaged values of the 


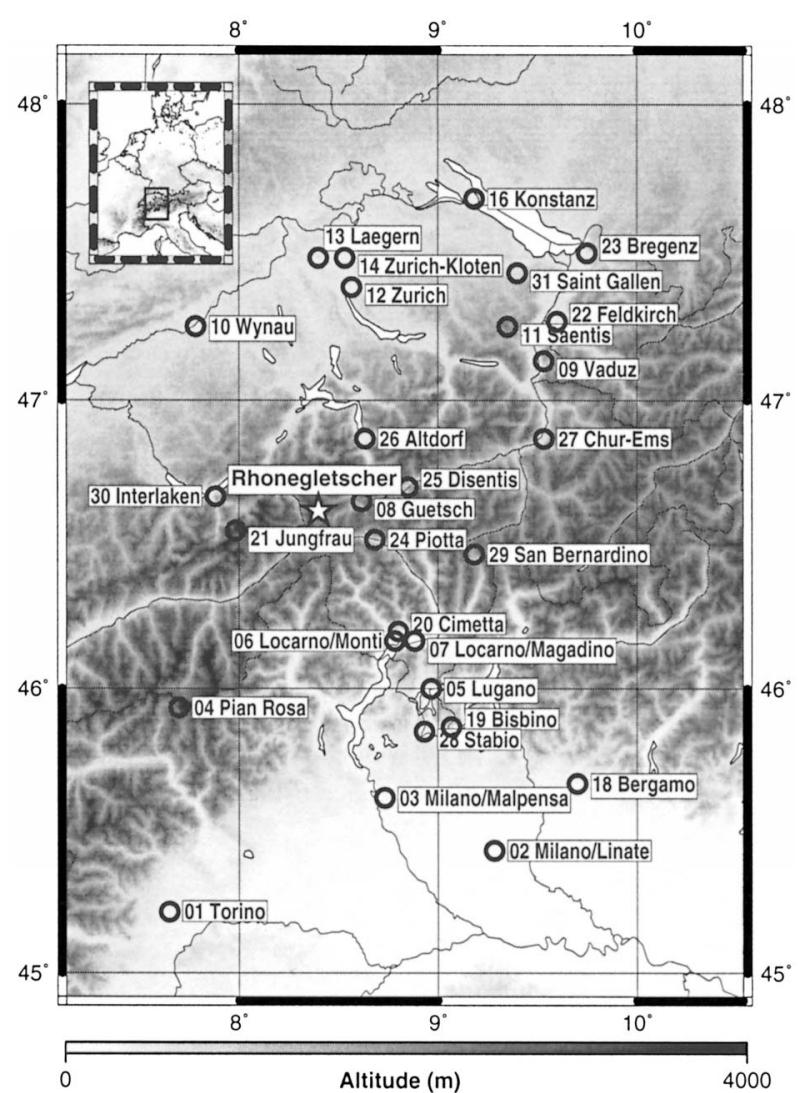

FIG. 1. Location of Rhonegletscher $\left(46^{\circ} 37^{\prime} \mathrm{N}, 8^{\circ} 24^{\prime} \mathrm{E}\right)$ and operational weather stations used for statistical downscaling. Local temperature and precipitation are simulated from GCM output on the basis of daily large-scale predictors obtained from ECMWF reanalyses and daily station data in the vicinity of the glacier.

original daily statistical model output, after removing the seasonal cycle, have been used. The explained variance can be split among the large-scale predictors from ECMWF reanalyses chosen by the statistical model in order to demonstrate their individual impact. Only predictors above the 850 -hPa level have been used (Reichert et al. 1999).

For observed local temperature, the explained variance $r^{2}$ averaged over all stations is $80.0 \%$ (correlation coefficient $r=0.9$ ). Dominant large-scale predictors are temperature at $850 \mathrm{hPa}(\mathrm{EV}: 41.3 \%)$, a seasonal cycle predictor (cosine function with a period of $1 \mathrm{yr}$, extrema at 1 Jan and 1 Jul; EV: 14.2\%; see Reichert et al. 1999), geopotential thickness at 700-850 hPa (EV: 8.0\%), and relative humidity at $850 \mathrm{hPa}(\mathrm{EV}: 5.9 \%)$. However, the composition of predictors changes significantly between individual stations. Stations 08 Guetsch and 11 Saentis are located at high elevations (2284 and $2500 \mathrm{~m}$, respectively). Here, the only predictor chosen by the model is geopotential thickness at $700-850 \mathrm{hPa}$, explaining more than $95 \%$ of the monthly averaged local temperature. For station 21 Jungfrau (elevation: $3576 \mathrm{~m}$ ) the predictors are geopotential thickness at 500-850 and at
400-500 hPa together explaining 94\% of the observed values. The predominant predictor for all other stations (elevations below $1700 \mathrm{~m}$ ) is generally large-scale temperature at $850 \mathrm{hPa}$.

For observed local precipitation, both the explained variance as well as the spatial homogeneity of predictors are generally lower than for temperature, as can be expected. The characteristic composition of predictors is dependent on the meridional location of the stations within the area of investigation. Stations located more in the south of the Alps (stations 01, 03, 05, 06, 07, 19, 20 , and 28) show a more uniform composition of predictors than other stations. The averaged explained variance in this area is $60 \%$, predominant predictors are vorticity at $700 \mathrm{hPa}(\mathrm{EV}$ about $15 \%)$, zonal wind at 700 $\mathrm{hPa}(\mathrm{EV}: 15 \%-20 \%)$, and vertical velocity at $500 \mathrm{hPa}$ (EV: $10 \%-15 \%)$. For stations located in the north (stations 09-12, 16, 22, 23, 31) and the central parts of the Alps (stations 08, 21, 24-27, 29, 30), vertical velocity at $850 \mathrm{hPa}$ plays as important role (EV: $15 \%-25 \%$ for some stations) in addition to vorticity at $700 \mathrm{hPa}(\mathrm{EV}$ : up to $15 \%$ ). Also meridional wind at $850 \mathrm{hPa}$ (EV: $5 \%-$ $15 \%$ ) and at $700 \mathrm{hPa}$ (particularly for stations 10, 12, and 16; EV: $10 \%-15 \%$ ) can have a considerable additional impact, dependent on the local setting of the stations.

Among all stations, station 08 Guetsch $\left(46^{\circ} 39^{\prime} \mathrm{N}\right.$, $8^{\circ} 37^{\prime} \mathrm{E}$ ) is the closest station to Rhonegletscher (Fig. 1) and also its altitude $(2284 \mathrm{~m})$ lies within the altitudinal range of the glacier. This station is therefore used to represent the local climate of the glacier site for the simulation of glacier fluctuations. The explained variance for observed local temperature is $97 \%$ while the explained variance with respect to the month-to-month variability of local precipitation is below the average over all stations (51\%). However, as Fig. 2 demonstrates, the simulated mean monthly precipitation for the period 1979-93, which will be most important for the seasonal sensitivity characteristic (SSC) of the glacier (section 3c), is improved substantially as compared with direct ECMWF reanalyses, and agrees well with the observed precipitation means (correlation coefficient $r=0.82 ; 95 \%$ significant for $r \geq 0.57)$. The statistical model was validated using independent data as described in Reichert et al. (1999).

\section{c. Downscaling for Nigardsbreen}

Nigardsbreen is a temperate outlet glacier of Jostedalsbreen, Norway, the largest ice cap of the European continent. It is located in Norway $\left(61^{\circ} 43^{\prime} \mathrm{N}, 7^{\circ} 08^{\prime} \mathrm{E}\right)$; its elevation ranges from 295 to $1950 \mathrm{~m}$ above sea level. The total area of the glacier is $47 \mathrm{~km}^{2}$ (Hoelzle and Haeberli 1999). Among other maritime glaciers in western Norway, Nigardsbreen is selected in this study since detailed investigations using an energy-balance model have been carried out (Oerlemans 1992), and a dynamic 
Precip. (mm/mo) 1979-1993

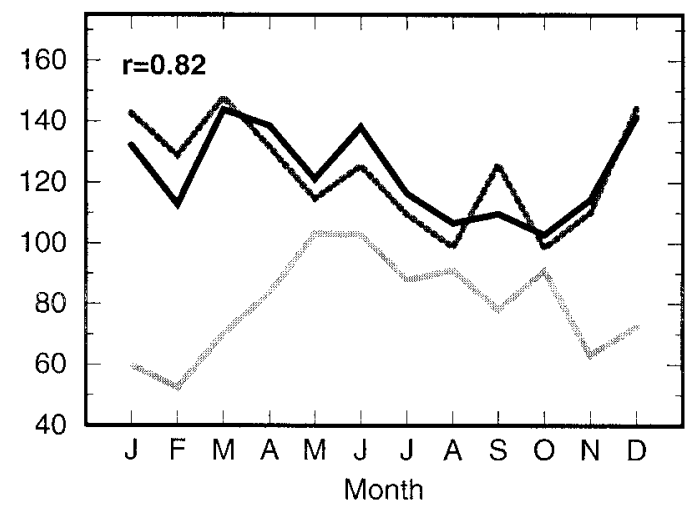

Direct Reanalyses

- Observed Data

Statistical Simulation

FIG. 2. Monthly means of precipitation averaged over the period 1979-93 for station Guetsch $\left(46^{\circ} 39^{\prime} \mathrm{N}, 8^{\circ} 37^{\prime} \mathrm{E}\right)$. Observed station data (dotted line), statistically downscaled results (solid line), and interpolated reanalyses without statistical modeling (shaded line) are shown. The simulated precipitation is in good agreement with observations (correlation coefficient $r=0.82$ ).

ice-flow model (Oerlemans 1997) for intended application in future studies exists for this glacier.

The location of stations for Nigardsbreen and the complete application of the downscaling approach used in this study is described in Reichert et al. (1999). The explained variance for local temperature (79\%) averaged over 17 available stations in the vicinity of the glacier (Laerdal-Tonjum, Vangsnes, Førde-Vie, Fortun, Finse III, Modalen II, Ona II, Tingvoll-Hanem, Hjelvik I Romsdal, Alesund/Vigra, Tafjord, Lesjaskog, Voss-Bo, Geilo-Geilostolen, Kvamskogen, Olden-Vangberg, and Bråtå) is comparable to the average for Rhonegletscher. The explained variance for local precipitation (65\%) is, however, higher in comparison with Rhonegletscher. This is due to the fact that for the Nigardsbreen area, local precipitation is already rather well determined by large-scale vertical velocity at $850 \mathrm{hPa}$ explaining more than $41 \%$ of variance alone. In this area, station Vangsnes $\left(61^{\circ} 10^{\prime} \mathrm{N}, 6^{\circ} 39^{\prime} \mathrm{E}\right)$ will be used for the simulation of glacier fluctuations.

\section{Sensitivity of glacier mass balance to meteorological data}

In this study, the sensitivity of mass balance to meteorological data is represented by glacier-specific seasonal sensitivity characteristics (Oerlemans and Reichert 2000) calculated from a mass balance model of intermediate complexity (Oerlemans 1992). In the following, a brief summary of this approach will be given.

\section{a. The mass balance model}

The specific mass balance $M$ of a glacier is the resultant of all processes in a year that lead to mass gain or loss at the surface on a unit area [expressed in $\mathrm{m}$ water equivalent (mwe)].

The mean specific mass balance $B$ over the entire glacier can be expressed as

$$
B=\frac{1}{S_{T}} \sum_{i} M\left(h_{i}\right) S\left(h_{i}\right)
$$

with a discrete elevation-area distribution $S\left(h_{i}\right)$, the total glacier area $S_{T}$, and the sum taken over all elevation intervals centered around the elevation $h_{i}$.

In principle, the mass balance model integrates the energy-balance equation for the ice/snow surface in time, on a grid covering the entire elevation range:

$$
\Psi=(1-\alpha) G+I_{\text {in }}+I_{\text {out }}+H_{s}+H_{l} .
$$

Here, the energy balance $\psi$ is expressed in terms of the absorbed solar radiation (albedo $\alpha$, global radiation $G)$, the incoming and outgoing longwave fluxes $\left(I_{\text {in }}\right.$ and $I_{\text {out }}$ ), and the turbulent fluxes of sensible and latent heat $\left(H_{s}\right.$ and $\left.H_{l}\right)$. As soon as the energy balance becomes positive, melting occurs at the surface.

The specific mass balance $M$ can then be written as

$$
M=\int_{\text {year }}\left[(1-f) \min \left(0 ;-\Psi L^{-1}\right)+P^{*}\right] d t
$$

with $L$ as the latent heat of melting, $f$ as the fraction of meltwater that refreezes and does not contribute to mass loss, and $P^{*}$ as the accumulation rate at which solid precipitation is added to the surface.

The albedo $\alpha$ represents a major problem because of significant feedbacks and strong variations in space and time depending on the melt and accumulation history itself. The model generates the albedo internally using a simple scheme, so that main features broadly match available data from valley glaciers. A "background albedo profile" is empirically developed so that typical albedo patterns of a valley glacier at the end of the ablation season are matched. This profile, snow depth, and an age-independent snow albedo are then used for the calculation of the glacier albedo.

Refreezing (meltwater does not run off, but penetrates into the snowpack) is considered in the model, specifying the relationship between the fraction of melt energy involved in runoff and the snow/ice temperature (Oerlemans 1992).

\section{b. Seasonal sensitivity characteristic}

In order to quantify the climate sensitivity of the mean specific balance $B$ of a glacier and to apply it to downscaled GCM output, an SSC is used in this study (Oerlemans and Reichert 2000). It represents the dependence of $B$ on monthly perturbations in temperature and pre- 

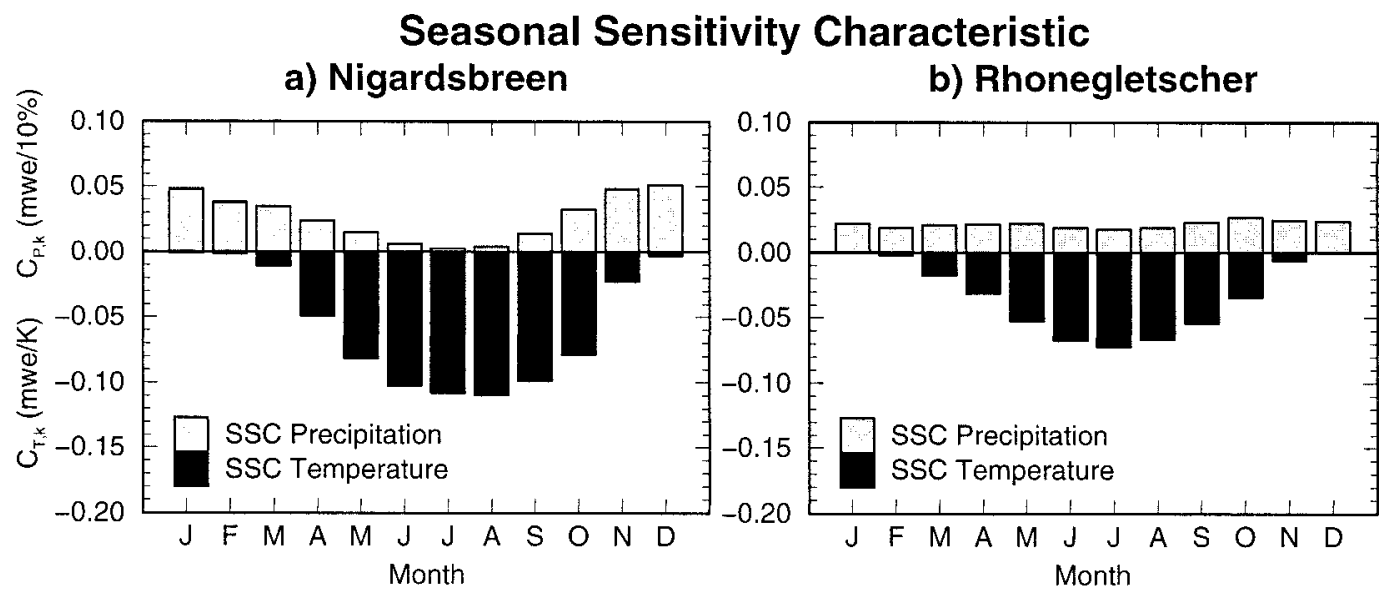

FIG. 3. Glacier-specific SSC for (a) Nigardsbreen and (b) Rhonegletscher. The SSC represents the dependence of glacier mass balance on monthly anomalies in temperature (solid bars) and precipitation (shaded bars). For Nigardsbreen, a $1^{\circ} \mathrm{C}$ temperature increase in summer (JJA) would, for example, roughly have the same effect $(0.1$ mwe in mass balance) as a $20 \%$ decrease of precipitation in winter (DJF).

cipitation and has been calculated from the mass balance model described above. Annual deviations $\Delta B$ of the mean specific balance $B$ are expressed as

$$
\Delta B=\sum_{k=1}^{12}\left[c_{T, k}\left(T_{k}-T_{\mathrm{ref}, k}\right)+c_{P, k}\left(P_{k} / P_{\mathrm{ref}, k}\right)\right]+H
$$

with the sum taken over all months of the year. Here, $T_{k}$ and $P_{k}$ represent monthly temperature and precipitation, $T_{\text {ref }, k}$ and $P_{\text {ref }, k}$ are climatological means of monthly values, and $H$ represents nonlinear terms (which can be neglected for glaciers considered in this study; Oerlemans and Reichert 2000).

The coefficients

$$
c_{T, k}=\frac{\partial B}{\partial T_{k}} \quad \text { and } \quad c_{P, k}=\frac{\partial B}{\partial\left(P_{k} / P_{\text {ref }, k}\right)}
$$

have been determined by the mass balance model and represent the 24 values of the SSC. They quantify the change in mass balance resulting from a change in monthly temperature (unit of $c_{T, k}$ : mwe $\mathrm{K}^{-1}$ ) and from a relative change in monthly precipitation (unit of $c_{P, k}$ : mwe), respectively.

The differences between using SSCs to reconstruct a mass balance series and using the full mass balance model itself have been tested and are found to be small (Oerlemans and Reichert 2000). They are therefore not relevant for the purpose of the present study.

\section{c. Sensitivity of Nigardsbreen and Rhonegletscher}

The specific SSCs for Nigardsbreen and Rhonegletscher with respect to temperature and precipitation are shown in Fig. 3.

Nigardsbreen (Fig. 3a) can be identified having maritime character. The melt season especially on the lower parts of the glacier is long, the sensitivity $c_{T, k}$ to changes in temperature remains high from May to October $\left(-0.08\right.$ to -0.11 mwe $\left.\mathrm{K}^{-1}\right)$. Temperature anomalies during these months therefore lead to a strong response in mass balance. On the other hand, a temperature change in winter [Dec-Jan-Feb (DJF)] has almost no effect since melting hardly occurs. The sensitivity of mass balance to relative changes in precipitation is very low in summer [Jun-Jul-Aug (JJA)] as compared with the winter values. The reason is that summer precipitation falls as rain over most parts of the glacier. An increase in precipitation has therefore only a marginal effect in comparison with the enhancement of mass balance in winter when precipitation mainly falls as snow and can be added to the surface.

The accumulation area of Rhonegletscher (Fig. 3b) is located at higher altitudes $(2140-3620 \mathrm{~m})$ in comparsion with Nigardsbreen $(295-1950 \mathrm{~m})$. The annual air temperature at the equilibrium line of the glacier (characterizing the glacier in its climatic and topographic setting) is lower when compared with Nigardsbreen. As a consequence, although summer precipitation (with a large fraction falling as snow at these altitudes) has a considerable effect on the annual mass balance, the sensitivity is in fact only slightly lower than in winter. With respect to changes in monthly temperature, Rhonegletscher is less sensitive $\left(-0.07\right.$ mwe $\mathrm{K}^{-1}$ in summer) than Nigardsbreen $\left(-0.11\right.$ mwe $\mathrm{K}^{-1}$ in summer).

\section{Validation of glacier mass balance using ECMWF reanalyses}

An opportunity to validate the entire process-based modeling approach applied in this study, including the statistical downscaling strategy and the simulation of mass balance using SSCs, is the simulation of glacier mass balance using ECMWF reanalyses. Simulated 


\section{Mass Balance Simulated Using Reanalyses a) Nigardsbreen}
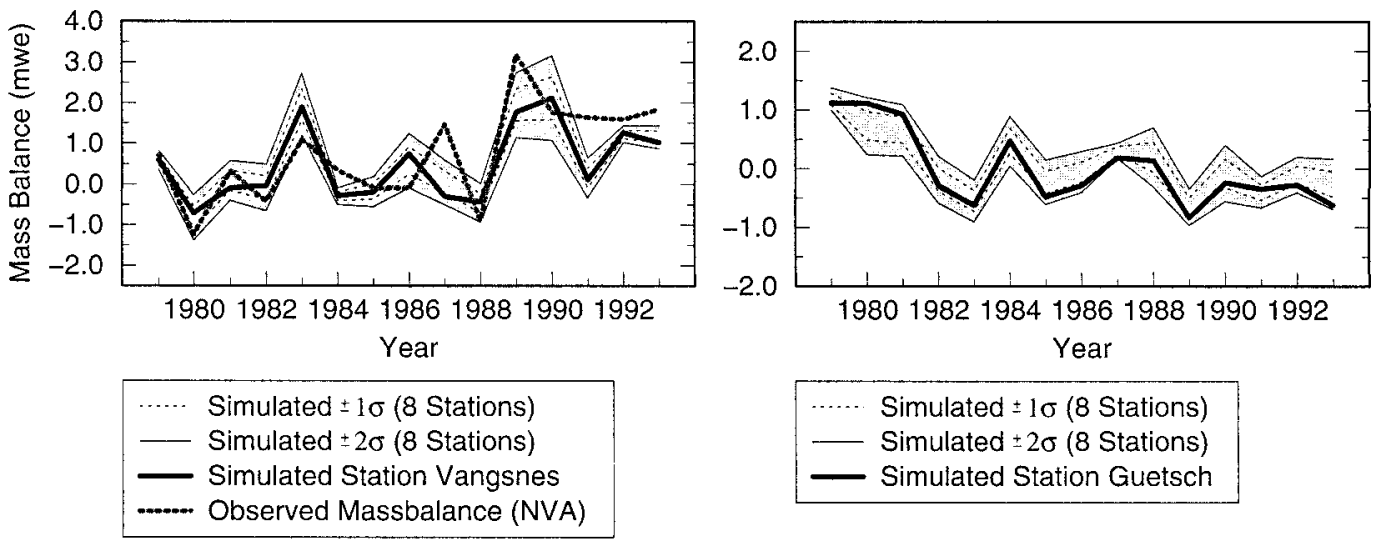

FIG. 4. Process-based glacier mass balance simulations for (a) Nigardsbreen and (b) Rhonegletscher using ECMWF reanalyses. Observational data of eight weather stations in the vicinity of each glacier are used for statistical downscaling. The gray shaded area represents the variability due to the choice of the station (mean over all stations \pm 2 std dev $\sigma$ ). Heavy solid lines denote simulated mass balances using (a) station Vangsnes and (b) station Guetsch. The heavy dotted line shows in situ measurements of mass balance for (a) Nigardsbreen.

mass balance records can be compared to actual in situ measurements of mass balance for the period 1979-93.

For the glacier Nigardsbreen (Fig. 4a), reliable measurements have been carried out by the Norwegian Water Resources and Energy Administration [Norges Vassdrags- og Energiverk; Østrem et al. 1988; International Association of Hydrological Sciences (IAHS)/UNESCO 1998, 1999]. These in situ measurements (Fig. 4a, thick dotted line) are in good agreement with the simulated mass balance using our process-based approach applied to ECMWF reanalyses. Glacier mass balance using data of eight operational weather stations in the vicinity of the glacier [stations Laerdal-Tonjum, Vangsnes, FørdeVie, Fortun, Finse III, Modalen II, Olden-Vangberg, and Bråtå; see Reichert et al. (1999) for locations] has been simulated. The gray shaded area in Fig. 4a represents the variability of mass balance due to the choice of the station (mean over all stations $\pm 2 \operatorname{std} \mathrm{dev} \sigma$ ). In spite of some years, for which the model produces a significantly lower than observed mass balance (mainly 1987 and 1991), the overall correlation between simulations and measurements is remarkably high. Within the relatively short time period investigated, the correlation coefficient for the mean over all stations is $r=0.78$. The heavy solid line denotes the mass balance simulation for station Vangsnes, which will be used for the GCM experiments described in section 5 and 6 .

For Rhonegletscher (Fig. 4b), exact measurements of mass balance are not available. However, for the recent variability of mass balance of this glacier, a standard deviation of about 0.6 mwe can be inferred according to numerous mass balance measurements in the central Alps (IAHS/UNESCO 1998). The standard deviation of the simulated mass balance using station Guetsch (solid line) is 0.62 mwe. Because of the relatively short time period of the ECMWF reanalyses, this agreement is not representative; it shows, however, that the variability of simulations for this glacier is generally comparable to measurements. Station Guetsch will be used for the GCM experiments in sections 5 and 6. The approach has again been applied to eight stations (stations Guetsch, Piotta, Disentis, Interlaken, San Bernadino, Cimetta, Chur-Ems, and Vaduz; see Fig. 1 for locations) in order to get an insight into the spatial homogeneity of mass balance (Fig. 4b, gray shaded area). The standard deviation exclusively due to spatial inhomogeneity between all eight stations, averaged over the entire time period is 0.18 mwe. For Nigardsbreen, we find 0.26 mwe for this quantity. Both values clearly demonstrate the considerable impact on glacier mass balance when using different stations in the vicinity of the glaciers.

The above experiments have enabled the validation of the process-oriented modeling approach applied in this study against observations. Although the demonstrated scatter of mass balance due to the choice of stations is not at all negligible, the results can be considered satisfactory with regard to the purpose of the analysis following below. They represent an important basis for the application to GCM experiments.

\section{Simulation of glacier mass balance using ECHAM4 GCM integrations}

The GCM integrations used in this study have been performed using a current state-of-the-art climate model, the fourth generation of the European Centre/Hamburg general circulation model (ECHAM4) developed at the Max-Planck-Institut für Meteorologie and the Deutsches Klimarechenzentrum, both in Hamburg, Germany (Roeckner et al. 1996). The origin of the model 
is the spectral weather prediction model of the ECMWF (Simmons et al. 1989). The version used in the present study has 19 levels in the vertical extending up to 10 $\mathrm{hPa}$. In order to characterize the role of the deep ocean for the simulation of low-frequency climatic variations, a coupled GCM (ECHAM4/OPYC) for comparison with a mixed-layer GCM (ECHAM4/MLO) without an internal ocean is used.

\section{a. Coupled GCM experiment (ECHAM4/OPYC)}

In this model version (Roeckner et al. 1999), ECHAM4 is coupled to the full ocean general circulation model OPYC [Oberhuber (1993); see Bacher et al. (1998) for coupling strategy] consisting of three submodels for the interior ocean, for the surface mixed layer, and for sea ice (dynamic-thermodynamic sea-ice model including viscous plastic rheology).

The experiment used is a control integration for present-day climatic conditions performed at T42 horizontal resolution (corresponding to a lat-long grid of about $\left.2.8^{\circ} \times 2.8^{\circ}\right)$. The concentrations of carbon dioxide, methane, and nitrous oxide are fixed at the observed 1990 values (Houghton et al. 1990, their Table 2.5). After a 100-yr spinup, the model has been integrated with constant flux adjustment (Roeckner et al. 1999) for 300 yr.

\section{b. Mixed-layer GCM experiment (ECHAM4/MLO)}

For this model version (Roeckner 1997), ECHAM4 is coupled to a mixed-layer ocean model (MLO) including a thermodynamic sea-ice model. The mixed layer has a fixed depth of $50 \mathrm{~m}$ and is horizontally insulated; an interior ocean is missing. Monthly means of heat are flux corrected using the observed climatological cycle of surface temperatures for the period 1979-88.

For the multicentury integration used in the present study, the spectral resolution of the atmospheric model has been reduced to T30 (corresponding to a lat-long grid of about $3.75^{\circ} \times 3.75^{\circ}$ ). However, the climatology and many aspects of its variability have been shown to be close to the T42 version of the model (Stendel and Roeckner 1998), whereas computational costs are significantly reduced. In this study, $590 \mathrm{yr}$ of a control integration for present-day climatic conditions (defined as for the coupled GCM; section 5a) are used.

\section{c. Mass balance simulations}

Mass balance simulations using the above GCM experiments have been performed for Nigardsbreen (Fig. 5a) and Rhonegletscher (Fig. 5b). Annual values of glacier mass balance (thin lines) and 10-yr low-pass-filtered values (heavy solid lines) are shown.

Pronounced mass balance fluctuations on timescales of years to decades have been simulated in the experiments. The variability in mass balance is exclusively due to internal variations in the climate system since GCM integrations excluding external forcings such as solar irradiation changes, volcanic, or anthropogenic effects are used. In order to compare the variability of the simulated time series, the standard deviations $\sigma$ for both the unfiltered and the 10-yr low-pass-filtered mass balance time series have been computed.

For both glaciers, the interannual variability for the mixed-layer GCM experiment (MLO) is higher (significant at $95 \%$ confidence level) in comparison with the coupled run (OPYC). For Nigardsbreen, we find $\sigma_{\mathrm{Nig}, \mathrm{MLO}}$ $=0.69$ mwe (MLO) as compared with $\sigma_{\mathrm{Nig}, \mathrm{OPYC}}=0.61$ mwe (OPYC). For Rhonegletscher, we have $\sigma_{\text {Rho,MLO }}=$ 0.91 mwe as compared with $\sigma_{\text {Rho, OPYC }}=0.79$ mwe. A further investigation shows that the main reason is the different variability in simulated precipitation in the two model versions (see section $6 b$ for the impact of precipitation on mass balance). Although the total amount of simulated annual precipitation averaged over the full time period of the experiments is comparable in both models, the standard deviation of precipitation for $\mathrm{Ni}$ gardsbreen (Rhonegletscher) is by $14 \%(12 \%)$ higher in the mixed-layer GCM relative to the coupled GCM. We assume that this model-specific feature is at least partly related to a different (and in comparison with observations more unrealistic) representation of the pattern of precipitation associated with the NAO in the mixedlayer model.

The standard variations of the 10-yr low-pass-filtered time series are not significantly different in the two model versions. They read as follows: $\sigma_{\mathrm{Nig}, \mathrm{MLO}}=0.30 \mathrm{mwe}$, $\sigma_{\mathrm{Nig}, \mathrm{OPYC}}=0.28 \mathrm{mwe}, \sigma_{\mathrm{Rho}, \mathrm{MLO}}=0.31 \mathrm{mwe}$, and $\sigma_{\text {Rho,OPYC }}=0.32$ mwe. This means that decadal-scale mass balance variability is actually comparable for the different GCM experiments. However, this is inconsistent with the fact that we would expect a lower variability on timescales of decades in the mixed-layer model due to the lack of an internal ocean. A spectral analysis of simulated averaged Northern Hemisphere temperature variations for both models suggests that this should at least be valid for periods longer than $40 \mathrm{yr}$ (Reichert 2000; Bengtsson and Reichert 2000). Nevertheless, this cannot be seen in the simulation for the specific midlatitude regions of Nigardsbreen and Rhonegletscher, which are strongly influenced by the NAO. One reason is the above-mentioned model-specific higher interannual mass balance variability (due to increased variability in precipitation) simulated by the mixed-layer GCM in comparison with the coupled model, which in turn also induces a higher decadal-scale variability. If the interannual variability was comparable in both models, a relatively lower decadal mass balance variability in the mixed-layer model would almost certainly be obtained, as could be expected.

For Nigardsbreen, the full record of observations for the period 1962-98 (Norwegian Water Resources and Energy Administration, see section 4) is shown for comparison (Fig. 5a). The variability of the observed annual 
a) Simulated Mass Balance Nigardsbreen

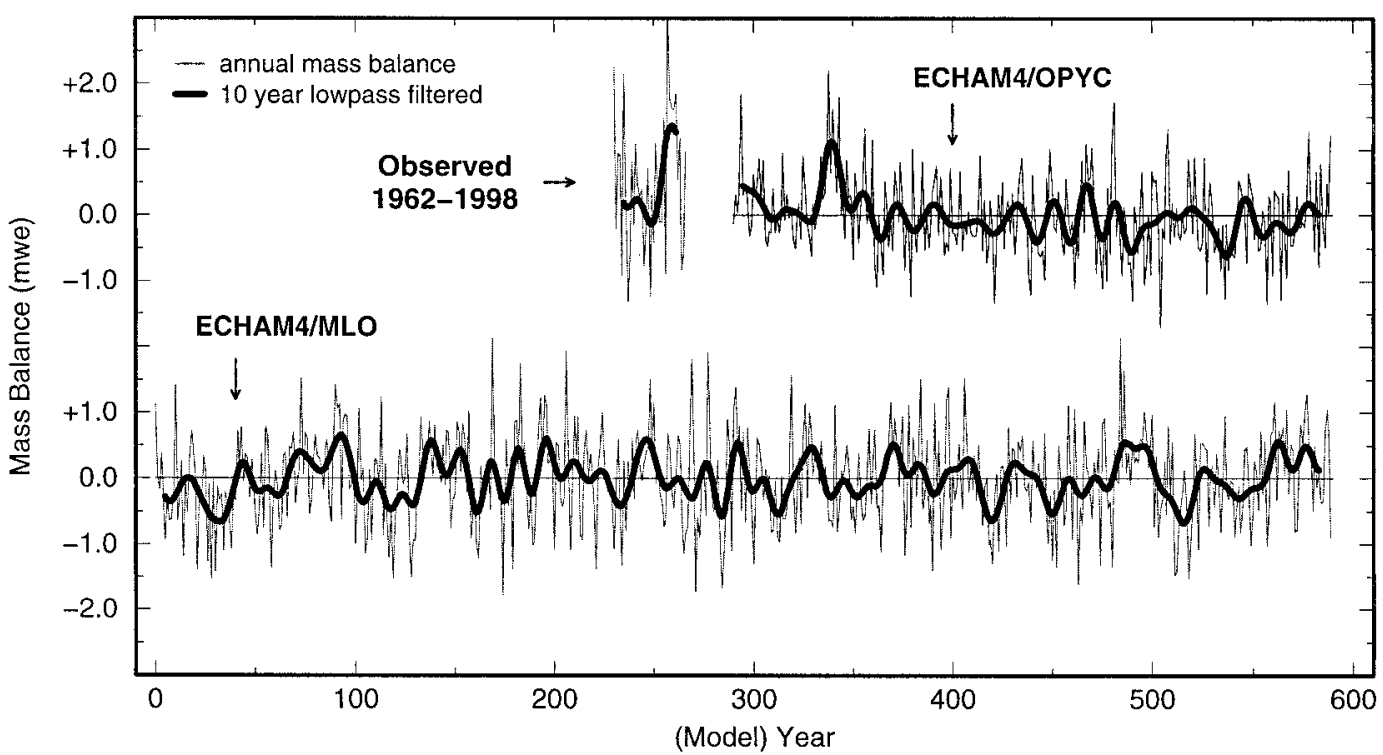

b) Simulated Mass Balance Rhonegletscher

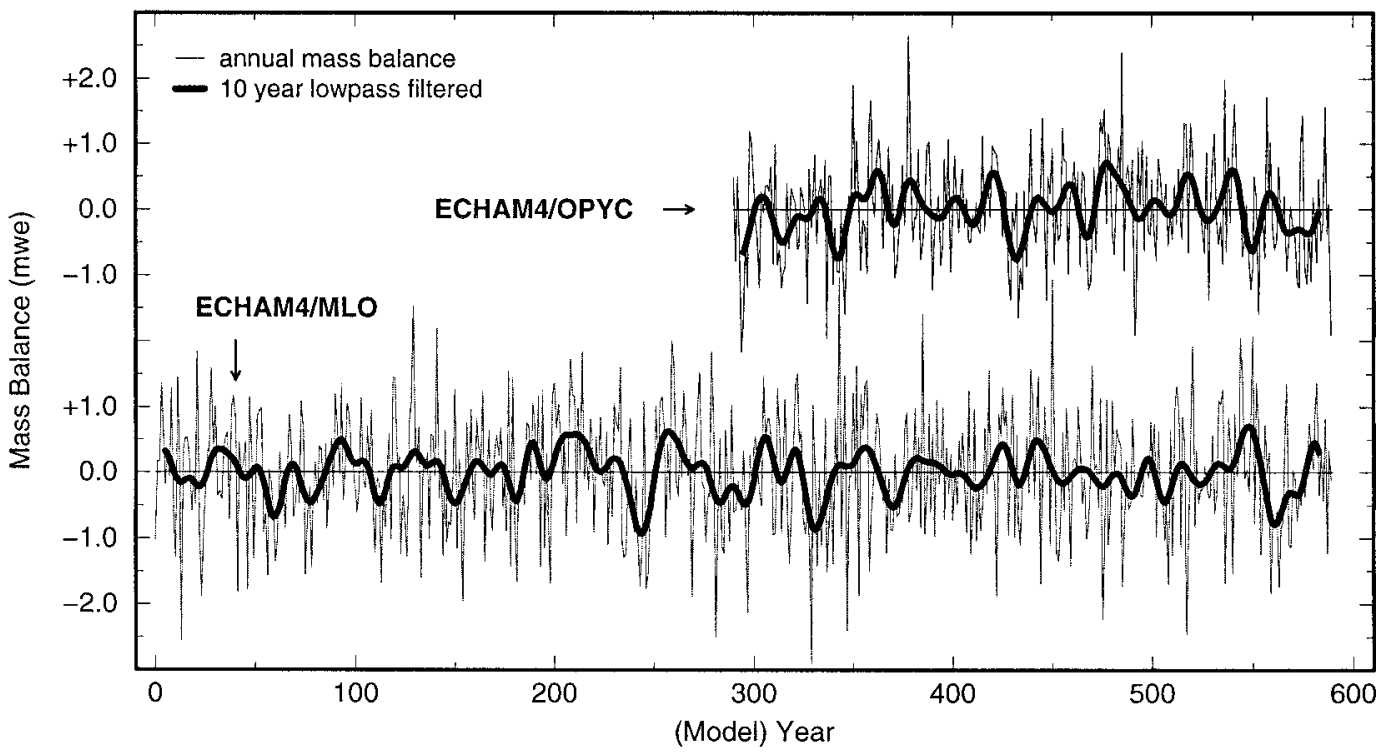

FIG. 5. Simulation of glacier mass balance exclusively due to internal variations in the climate system using coupled (ECHAM4/OPYC) and mixed-layer (ECHAM4/MLO) GCM experiments. Thin lines represent annual values of mass balance, and heavy solid lines denote the smoothed 10-yr low-pass-filtered versions for (a) Nigardsbreen and (b) Rhonegletscher. The observed mass balance for Nigardsbreen within the period 1962-98 is shown for comparison in (a).

mass balance is slightly higher than in the GCM control experiments. This will have three main reasons: 1) although the mass balance model explains a remarkably large part of observed glacier mass balance variations (as the experiments in section 4 have shown), some fraction of statistical variance is naturally missing in the simulation; 2) the large-scale variability in the GCM experiments serving as basis for statistical downscaling is slightly lower than in ECMWF reanalyses; and 3) the continuous increase of greenhouse gas concentrations not considered in the model runs (equilibrium state with constant greenhouse gas concentrations) affects climatic variability (this will be investigated in another study using transient coupled GCM experiments).

However, periods of generally strong positive mass balances, comparable to observed mass balances for Nigardsbreen during the 1980s and the first half of the 1990s (Fig. 5a, observed 1962-98 record; see Fig. 13 


\section{Sea Level Pressure}

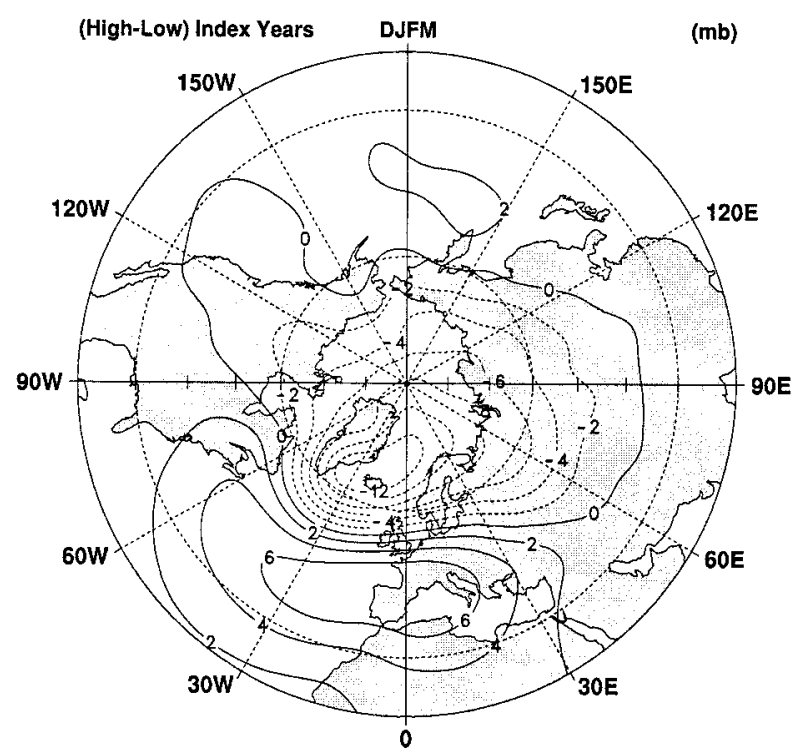

FIG. 6. Observed difference in sea level pressure for high NAO index minus low NAO index winters since 1899. The contour interval is $2 \mathrm{hPa}$; negative values are dashed (Hurrell 1995).

for larger illustration), do appear in the GCM simulations exclusively due to internal variations in the climate system. A comparable positive mass balance "event" has, for example, been simulated by the coupled ECHAM4/OPYC GCM at around year 50, denoted as year 340 in Fig. 5a (particularly evident for the 10-yr low-pass-filtered time series). It should also be mentioned that in longer coupled GCM integrations, the sampling problem would be reduced and a larger number of simulated events of this type could be expected. In the following, it will be demonstrated that such events can be related to the NAO (sections 6 and 7). A link to the NAO has been proposed in earlier studies (Hurrell 1995; Nesje et al. 2000) but can now be investigated in detail, including the responsible mechanisms using multicentury GCM experiments.

\section{The role of the NAO for glacier mass balance}

In this section, physical mechanisms in the climate system responsible for mass balance variations of the above-simulated glaciers are examined. This leads to an investigation of possible relationships with the NAO as a major source of atmospheric variability. The individual impact of temperature and precipitation on mass balance variations is examined, considering individual seasons that may have a distinct impact according to the glacier specific SSCs discussed in section 3.

\section{a. NAO index and glacier mass balance}

The NAO (Walker and Bliss 1932; van Loon and Rogers 1978; Kushnir and Wallace 1989; Kushnir 1994;

\section{Departure Pattern (Dec-Mar) 1935-1996}

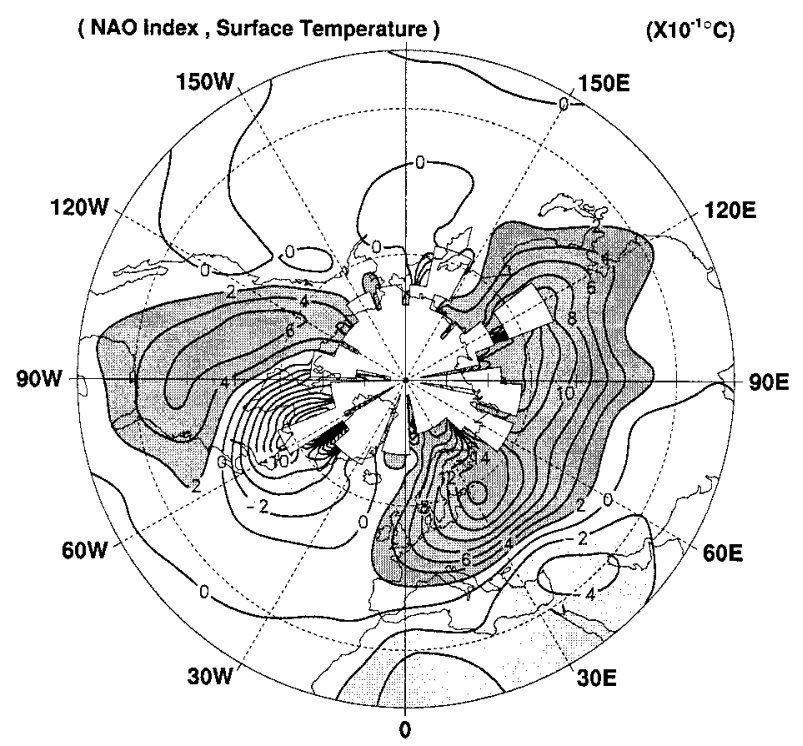

FIG. 7. Observed surface temperature change (unit: $0.1^{\circ} \mathrm{C}$ ) associated with a 1 std dev change in the NAO index. Data from Hurrell and van Loon (1997) for the winters of 1935-96 were used. Dark (light) shading indicates positive (negative) changes (Hurrell 1996).

Hurrell 1995; Visbeck et al. 1998) can be associated with variations in the strength of the westerlies over the North Atlantic onto Europe. A positive (negative) phase of the NAO reflects above-normal (below normal) pressure over the central North Atlantic south of $55^{\circ} \mathrm{N}$ and below-normal (above normal) pressure across the high latitudes of the North Atlantic (Fig. 6). One center is located near the semipermanent Icelandic low and the other center of opposite sign near the Azores high. The oscillation is present throughout the year in monthly mean data but is most pronounced during winter (Barnston and Livezey 1987).

Several hypotheses have been developed to explain the observed variability in the NAO. The null hypothesis is that the NAO is simply a natural internal mode in the climate system: the ocean turns high-frequency stochastic forcing of the atmosphere into low-frequency variability (Hasselmann 1976), which explains the observed redness of the spectrum. Spectral peaks may be due to damped eigenmodes associated with the coupling between ocean and atmosphere (Latif and Barnett 1994). The memory of the coupled system may be found in the gyral circulation of the ocean (Grötzner et al. 1998) and the thermohaline circulation (Timmermann et al. 1998).

The NAO has a dominant influence on wintertime temperatures of the Northern Hemisphere (Fig. 7). A strong positive phase of the NAO is related to a strong westerly flow over the North Atlantic (Rogers 1985) and can be associated with above-normal temperatures extending from northern Europe across much of Eurasia 


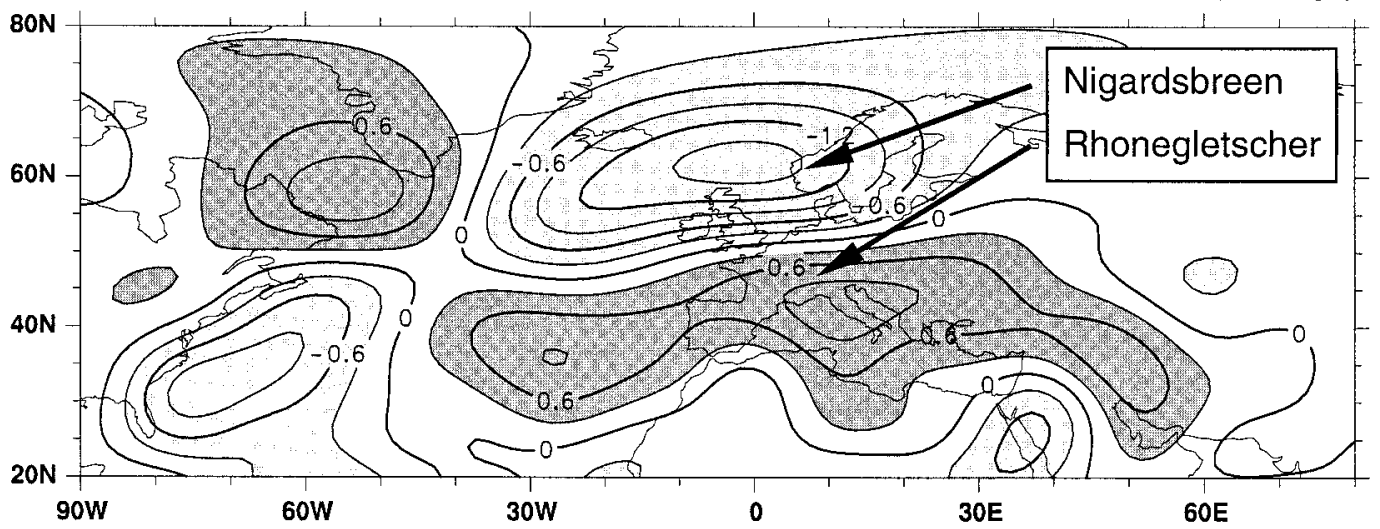

FIG. 8. Precipitation anomalies (unit: $\mathrm{mm} \mathrm{day}^{-1}$ ) associated with the NAO. Evaporation minus precipitation is plotted for high NAO index minus normal or low NAO index winters, computed as a residual of the atmospheric moisture budget using ECMWF global analyses (Hurrell 1995).

and below-normal temperatures over the northwest Atlantic (Hurrell 1995; Hurrell and van Loon 1997).

A considerable impact of the NAO on regional winter precipitation has also been observed (Fig. 8). HighNAO-index winters can be related to above-normal precipitation over an area spanning from Iceland to Scandinavia (particularly important for Nigardsbreen investigated in this study) and below-normal precipitation over much of central and southern Europe (important for Rhonegletscher in this study), the northern Mediterranean countries, and west North Africa (van Loon and Rogers 1978; Hurrell 1995).

Opposite patterns of temperature and precipitation anomalies are typically observed during pronounced negative phases of the NAO.

The NAO indices of the GCM integrations used in this study are constructed from the differences of normalized pressures in winter (Nov-Mar) between area averages located west of Portugal $\left(40^{\circ}-43^{\circ} \mathrm{N}, 11^{\circ}-\right.$ $\left.14^{\circ} \mathrm{W}\right)$ and over Iceland $\left(65^{\circ}-68^{\circ} \mathrm{N}, 17^{\circ}-20^{\circ} \mathrm{W}\right)$ following the definition of Hurrell (1995) (see Wallace and Gutzler 1981; Christoph et al. 1999). A positive index value is associated with stronger-than-normal westerlies across the North Atlantic and northwestern Europe, a negative value indicates weaker-than-normal westerlies.

Figure 9 shows the unfiltered (solid thin lines) and 10-yr low-pass-filtered time series (solid heavy lines) of the NAO index for $300 \mathrm{yr}$ of the coupled (ECHAM4/ OPYC) GCM integration. Glacier mass balance for Nigardsbreen (Fig. 9a, dotted line) and Rhonegletscher (Fig. 9b, dotted line) as simulated by the experiment (see section 5 for description) along with the 10-yr lowpass-filtered versions (heavy shaded lines) is shown for comparison. For both glaciers, a well-pronounced correlation between the low-pass-filtered NAO index of the model and mass balance is found. The correlation coefficient for Nigardsbreen is $r=0.55$. For Rhonegletscher, an anticorrelation of $r=-0.64$ is found (both significant at $99 \%$ confidence level). This demonstrates the strong link between decadal variations in the NAO and decadal variability in glacier mass balance controlled by temperature and precipitation. In the following, the individual role of temperature and precipitation within this relation will be further investigated.

\section{b. Individual impact of temperature and precipitation on mass balance}

The individual impact of temperature and precipitation on mass balance of each glacier is illustrated in Fig. 10. The 10-yr low-pass-filtered mass balances for Nigardsbreen (Fig. 10a) and Rhonegletscher (Fig. 10b) as simulated by the coupled GCM using exclusively either precipitation $\left(B_{P}\right.$, dashed shaded lines) or temperature ( $B_{T}$, dashed solid lines) have been calculated. For both glaciers, the mass balance variability due to precipitation (std $\operatorname{dev} \sigma_{B_{p}}$ ) is by far higher than the variability due to temperature $\left(\sigma_{B_{t}}\right)$. For Nigardsbreen, we find $\sigma_{B_{p}}=0.27 \mathrm{mwe}$ and $\sigma_{B_{t}}=0.17 \mathrm{mwe}$; for Rhonegletscher we have $\sigma_{B_{p}}=0.32 \mathrm{mwe}$ and $\sigma_{B_{t}}=0.10$ mwe. This means that the individual impact of precipitation on Nigardsbreen glacier mass balance is about 1.6 times higher than the impact of temperature. For Rhonegletscher it is about 3 times higher.

It can furthermore be inferred that, for both glaciers, changes in mass balance due to precipitation are very closely linked to the NAO (Fig. 10, solid lines). The correlation coefficient between $B_{P}$ and the NAO index is $r=0.75$ (Nigardsbreen) and $r=-0.65$ (Rhonegletscher). On the other hand, mass balance variations due to temperature are not significantly correlated with the NAO (95\% confidence level); we find $r=-0.20$ (Nigardsbreen) and $r=-0.17$ (Rhonegletscher). This suggests that, for both glaciers, precipitation is by far the dominant factor for the close relationship between glacier mass balance variations and the NAO. 
NAO Index and Mass Balance Nigardsbreen/Rhonegletscher

a) Nigardsbreen, Coupled GCM Control Run

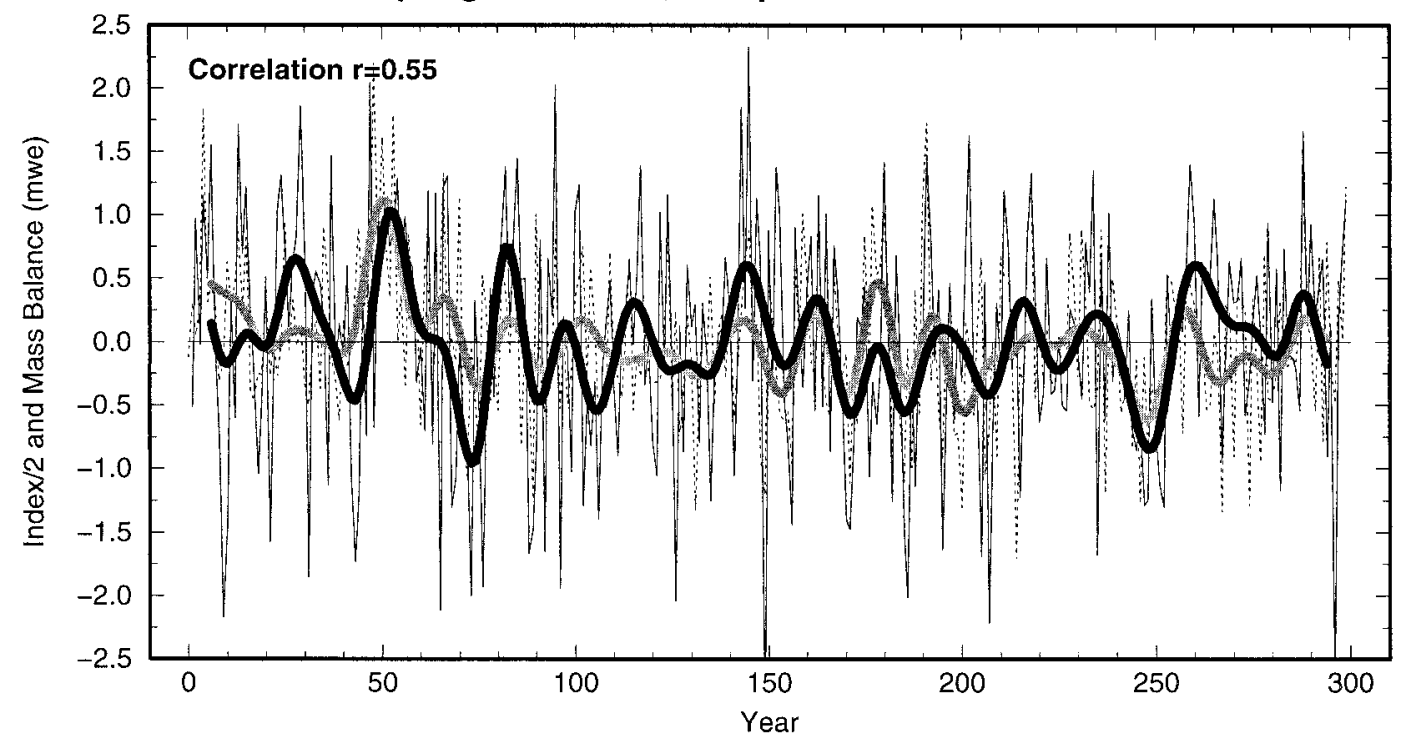

b) Rhonegletscher, Coupled GCM Control Run

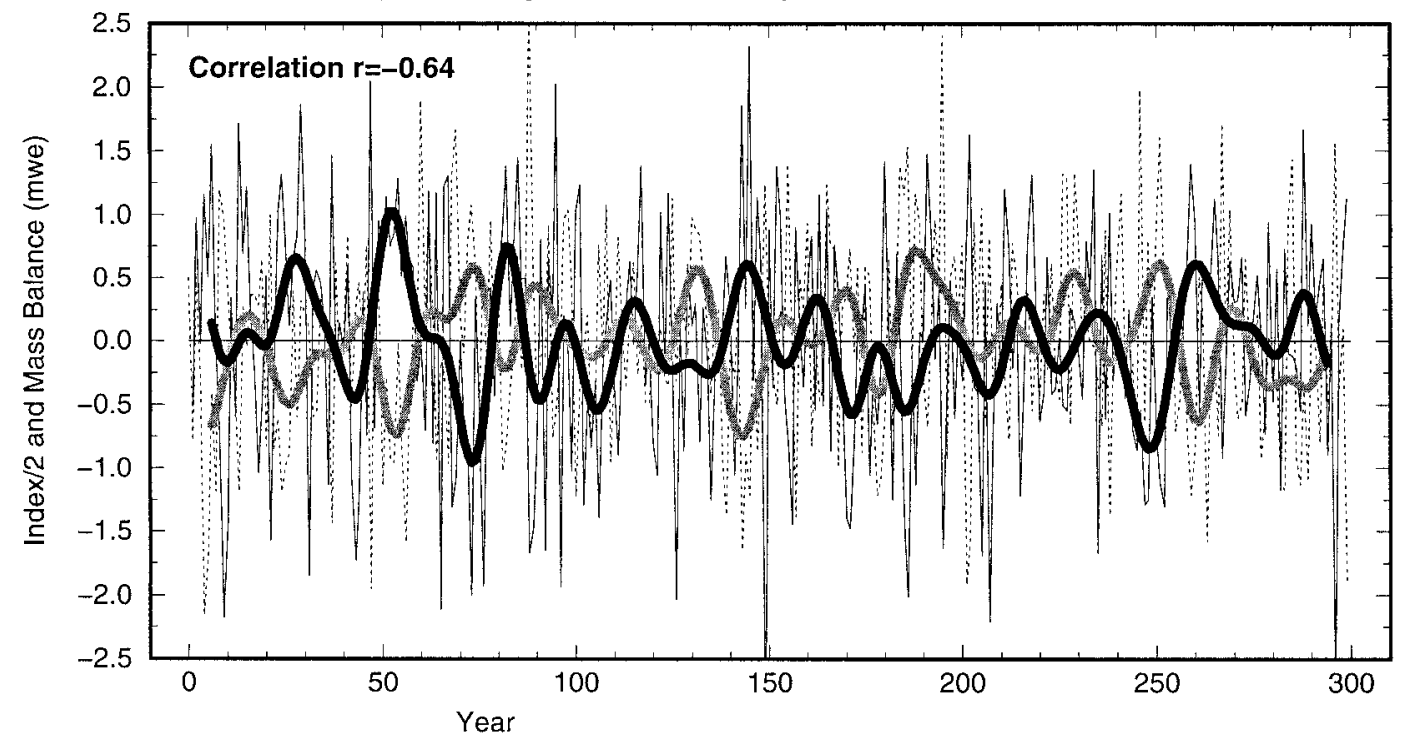

Simulated mass balance Nigardsbr./Rhonegl.

- NAO index from GCM control run

10 year lowpass filtered mass balance

- 10 year lowpass filtered NAO index

FIG. 9. NAO index (thin solid line) along with glacier mass balance of (a) Nigardsbreen and (b) Rhonegletscher (thin dotted line) as simulated by the coupled (ECHAM4/OPYC) GCM experiment. The figure illustrates the strong link between the NAO and glacier mass balance fluctuations; the correlation coefficients $r$ for the 10-yr low-pass-filtered time series (heavy lines) are shown in the top-left corner of each graph.

For the mixed-layer GCM experiment (not shown), the standard deviations $\sigma_{B_{t}}$ of mass balance due to temperature are comparable to the coupled GCM. The standard deviations $\sigma_{B_{p}}$ due to precipitation are slightly high- er (e.g., for Rhonegletscher 0.36 relative to $0.32 \mathrm{mwe}$ ) because of the model-specific increased variability in simulated precipitation. As mentioned in section 5c, this is connected to the different representation of the pattern 
Impact of Temperature and Precipitation on Mass Balance

a) Nigardsbreen, Coupled GCM Control Run

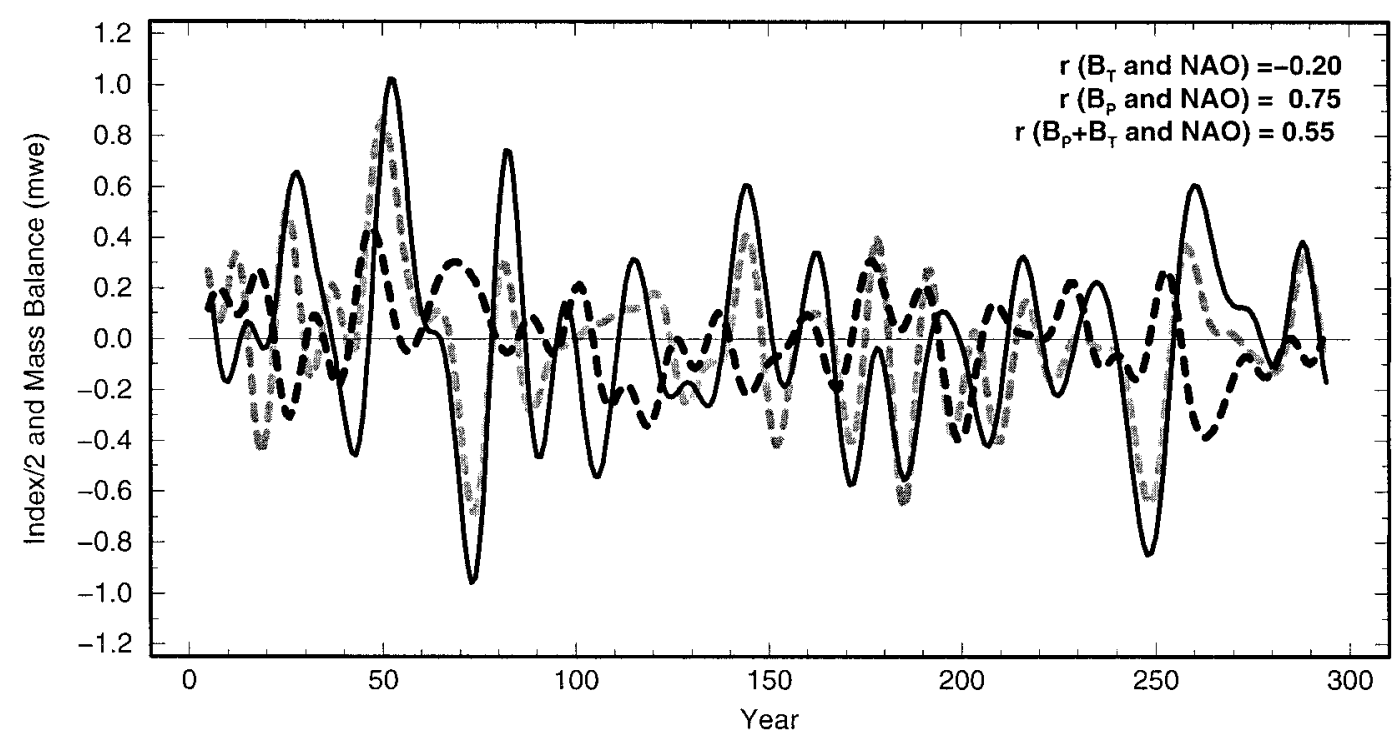

b) Rhonegletscher, Coupled GCM Control Run

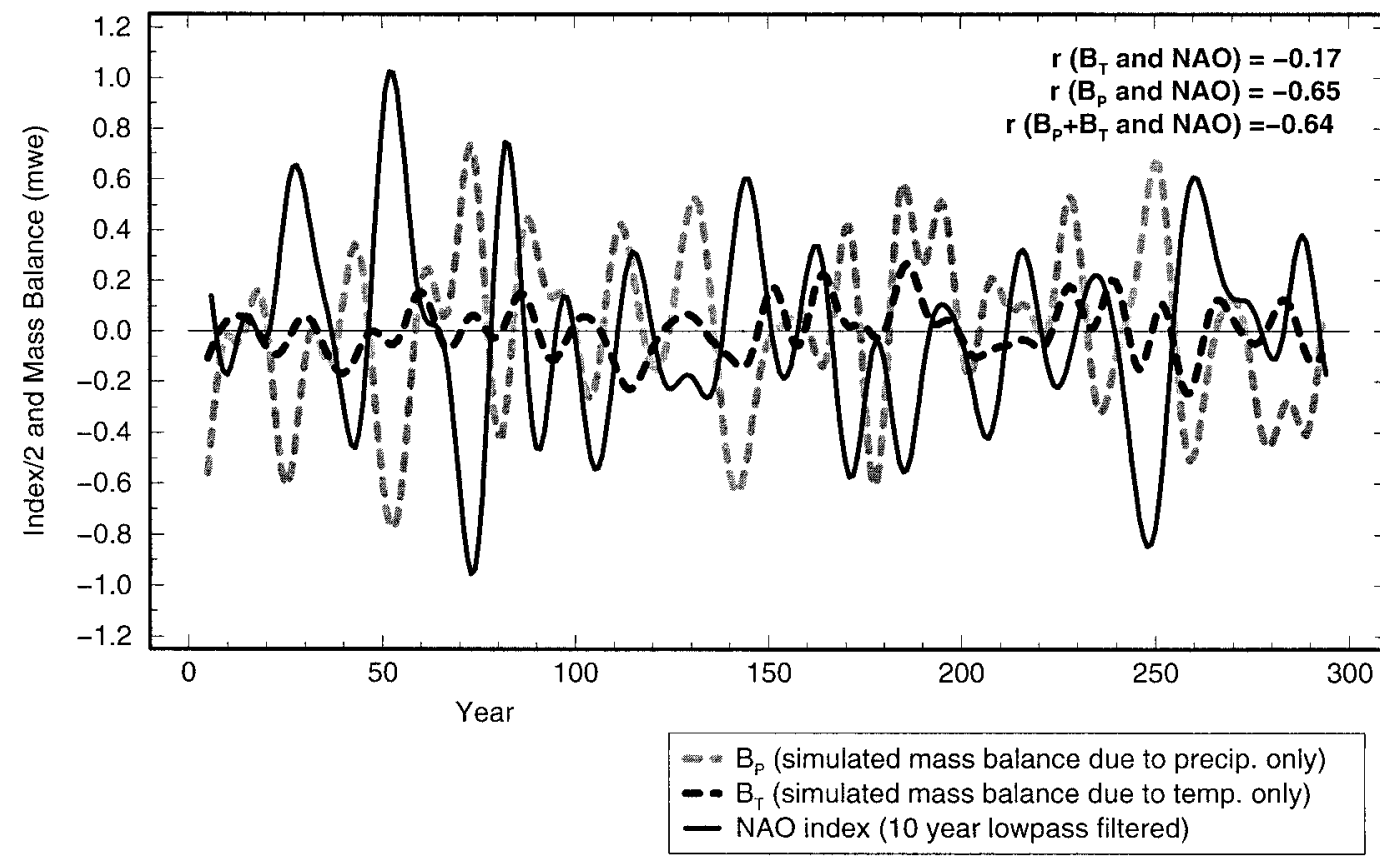

FIG. 10. Individual impact of temperature and precipitation on glacier mass balance for (a) Nigardsbreen and (b) Rhonegletscher as simulated by the coupled GCM (ECHAM4/OPYC). The 10-yr low-pass-filtered mass balance $B_{P}$ simulated using exclusively precipitation (shaded dashed lines), the mass balance $B_{T}$ exclusively due to temperature (solid dashed lines), and the NAO index (solid lines) are presented. Correlation coefficients between the NAO index on the one hand and $B_{P}, B_{T}$, and $B_{P}+B_{T}$ (resulting total mass balance as in Fig. 9), respectively, on the other hand are shown in the top-right corner of each graph. 

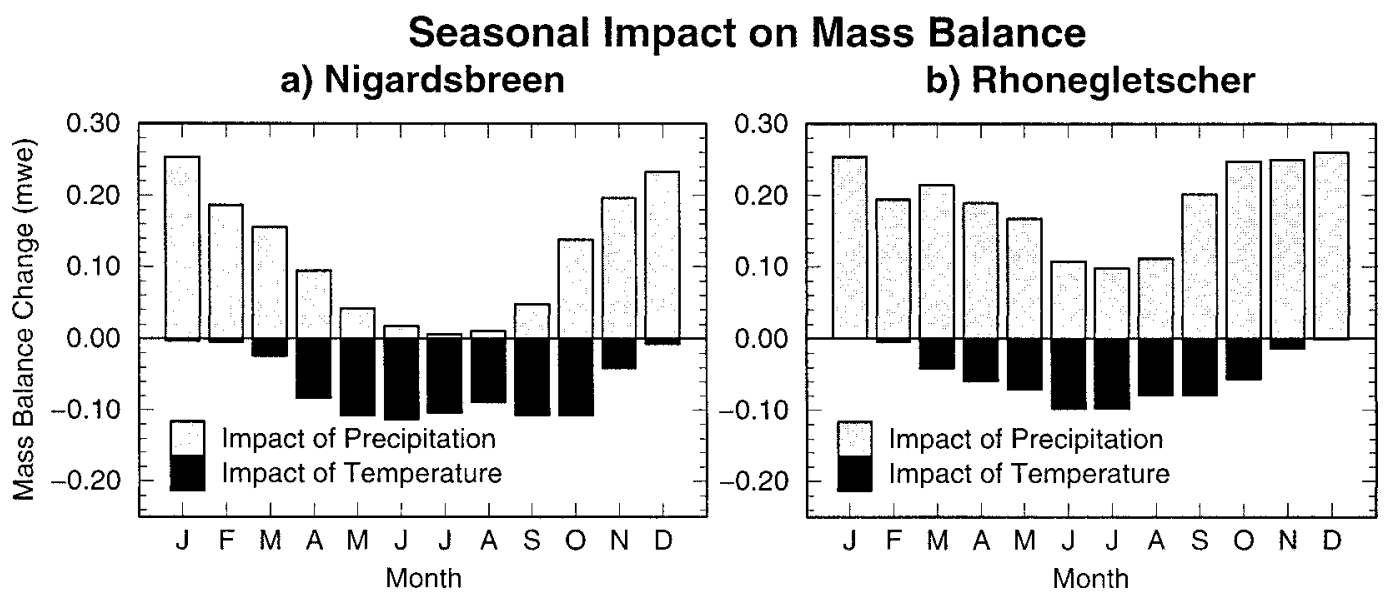

FIG. 11. Impact (defined as sensitivity $\times$ GCM-simulated variability) on glacier mass balance associated with a 1 std dev change in temperature and precipitation for individual months of the year for (a) Nigardsbreen and (b) Rhonegletscher. The SSC (Fig. 3) and the standard deviation of temperature and precipitation for a specific month as simulated by the downscaled coupled GCM experiment are considered.

of precipitation associated with the NAO in the mixedlayer model.

\section{c. Seasonal impact on mass balance}

The actual impact of temperature and precipitation on glacier mass balance for individual months of the year as simulated by the downscaled coupled GCM may now be investigated. For each glacier site, the standard deviations of the simulated temperature and precipitation variations for a specific month over $300 \mathrm{yr}$ of the control experiment are calculated. We define the impact as the standard deviations multiplied with the corresponding monthly sensitivity values of the glaciers obtained from the SSCs described in section 3c. This means that we account for both the sensitivity of the glaciers as well as the actually simulated local variability of the forcing variables. The resulting mass balance changes presented in Fig. 11 can be associated with a 1 standard deviation change of the forcing variables for individual months.

Although the SSCs as illustrated in Fig. 3 may at first glance have suggested a rather low overall sensitivity of both glaciers to precipitation changes, we find that the actual impact (sensitivity $\times$ GCM-simulated standard variation) of precipitation changes on mass balance is in fact relatively high in comparison with temperature (Figs. 11a,b). The reason is of course the relatively high variability in local precipitation as simulated by the downscaled GCM as compared with the variability in temperature. This is in agreement with the statement in section $6 \mathrm{~b}$ (Fig. 10) where we found that the impact of precipitation on the annual mass balance is much stronger (1.6 times for Nigardsbreen, 3 times for Rhonegletscher) than the impact of temperature.

For both glaciers, the simulated variability of temperature in the 300-yr GCM integration is generally highest in winter (DJF), which can partly be related to the influence of the NAO as will be discussed below. However, because of the very small temperature sensitivity in winter $\left(<0.01\right.$ mwe $\mathrm{K}^{-1}$, Fig. 3$)$, the overall impact of winter temperature changes is extremely small, in fact negligible (Fig. 11). On the other hand, we find that relatively small simulated temperature variations in summer (JJA) have a considerable impact on mass balance since the sensitivity of the glaciers is naturally high during this season (melting occurs, Fig. 3).

With respect to precipitation, we find a very strong impact on mass balance of the glaciers in winter (Fig. 11). This is naturally a consequence of the glacier's high sensitivity (Fig. 3) and the high variability in precipitation for this season (related to the NAO, see below). For Nigardsbreen, the sensitivity in summer (summer precipitation falls as rain over most parts of the glacier, section $3 \mathrm{c}$ ) and the variability in precipitation are small, the resulting impact is therefore low. For the higherelevated Rhonegletscher, even smaller summer temperature changes have a noticeable impact since the sensitivity to precipitation is nearly constant throughout the year (Fig. 3b).

\section{d. Seasonal impact of the NAO}

The seasonal impact on mass balance is now further investigated by examining extreme events of positive and negative NAO phases in the coupled GCM experiment along with their impact on temperature and precipitation. Figure 12 shows the situation during $10 \mathrm{yr}$ of a high phase of the NAO index (mean over model years 48-57, see Fig. 9) minus 10 years of the following low phase of the NAO index (mean over model years 69-78). The corresponding anomaly patterns of sea level pressure (Fig. 12a), surface air temperature (Fig. 12b), and precipitation (Fig. 12c) are presented for the winter 


\section{Simulated Winter Anomalies of Sea Level Pressure, Temperature, and Precipitation Associated with the NAO (ECHAM4/OPYC)}

a) Sea Level Pressure $[\mathrm{hPa}]$

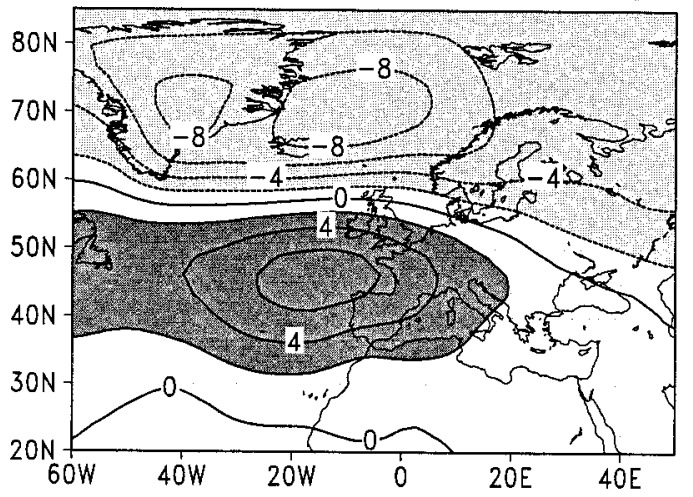

b) Surface Air Temperature $\left[{ }^{\circ} \mathrm{C}\right]$

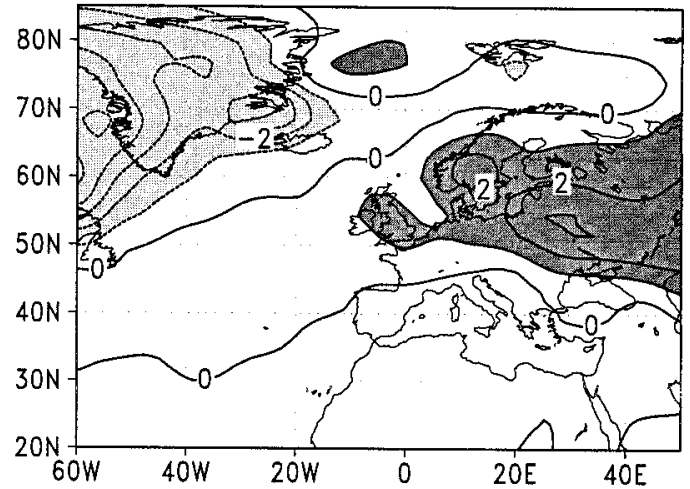

c) Precipitation $[\mathrm{mm} / \mathrm{month}]$

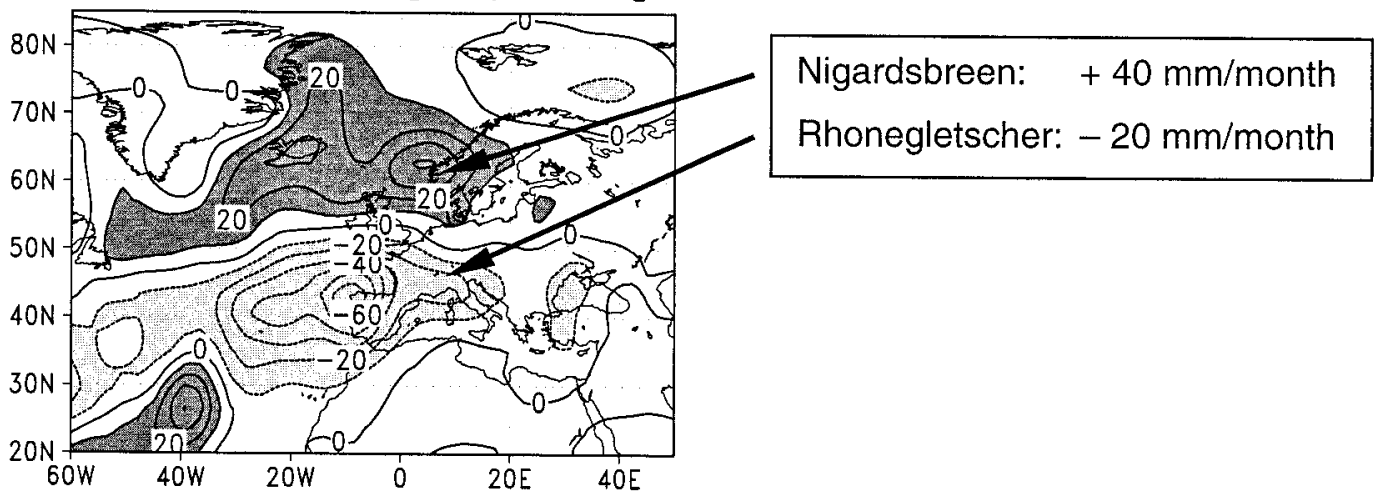

FIG. 12. Winter (DJF) anomalies of (a) sea level pressure (contour interval $2 \mathrm{hPa}$ ), (b) surface air temperature (contour interval $1^{\circ} \mathrm{C}$ ), and (e) precipitation (contour interval $10 \mathrm{~mm}$ month ${ }^{-1}$ ) associated with $10 \mathrm{yr}$ of a high phase minus 10 yr of a low phase of the NAO index as simulated by the coupled GCM. Dark (light) shading indicates positive (negative) anomalies. During summer (JJA; not shown), no distinct anomaly patterns are associated with the NAO.

(DJF) season. During summer (JJA; not shown), no distinct anomaly patterns are associated with the NAO, reflecting the fact that the NAO is not well pronounced during this season as mentioned earlier (section 6a).

The sea level pressure pattern in winter (Fig. 12a) is the typical NAO pattern and is realistically represented by the coupled GCM in comparison with observations (see Fig. 6).

\section{1) Seasonal impact of precipitation}

Positive anomalies in winter precipitation associated with the NAO (Fig. 12c) can be found from Iceland to Scandinavia, with a maximum anomaly of about $40 \mathrm{~mm}$ month $^{-1}$ near the Norwegian coast. The pattern is in good agreement with observations (Fig. 8). Negative anomalies occur over western and southern Europe with the largest reductions in precipitation (more than $60 \mathrm{~mm}$ month ${ }^{-1}$ ) near the northwestern coast of the Iberian Peninsula. The Alps experience a reduction of about $20 \mathrm{~mm}$ in monthly precipitation.

The glacier Nigardsbreen $\left(61^{\circ} 43^{\prime} \mathrm{N}, 7^{\circ} 08^{\prime} \mathrm{E}\right)$ is located near the maximum anomaly $\left(40 \mathrm{~mm} \mathrm{month}^{-1}\right)$ in winter precipitation associated with the NAO. As has been shown above, the glacier is most sensitive to winter precipitation anomalies (Fig. 11a). This demonstrates that the strong impact of precipitation on mass balance (as shown in Figs. 10a and 11a) can to a great extent be explained by the strong influence of the NAO. During summer, both the precipitation anomaly due to the NAO and the sensitivity of the glacier are low; the effect on mass balance is consequently very small.

For the region of Rhonegletscher $\left(46^{\circ} 37^{\prime} \mathrm{N}, 8^{\circ} 24^{\prime} \mathrm{E}\right)$, we find a reduction in winter precipitation of about 20 mm month ${ }^{-1}$ (Fig. 12c) exerting a strong impact on the annual mass balance of the glacier (as shown in Figs. 


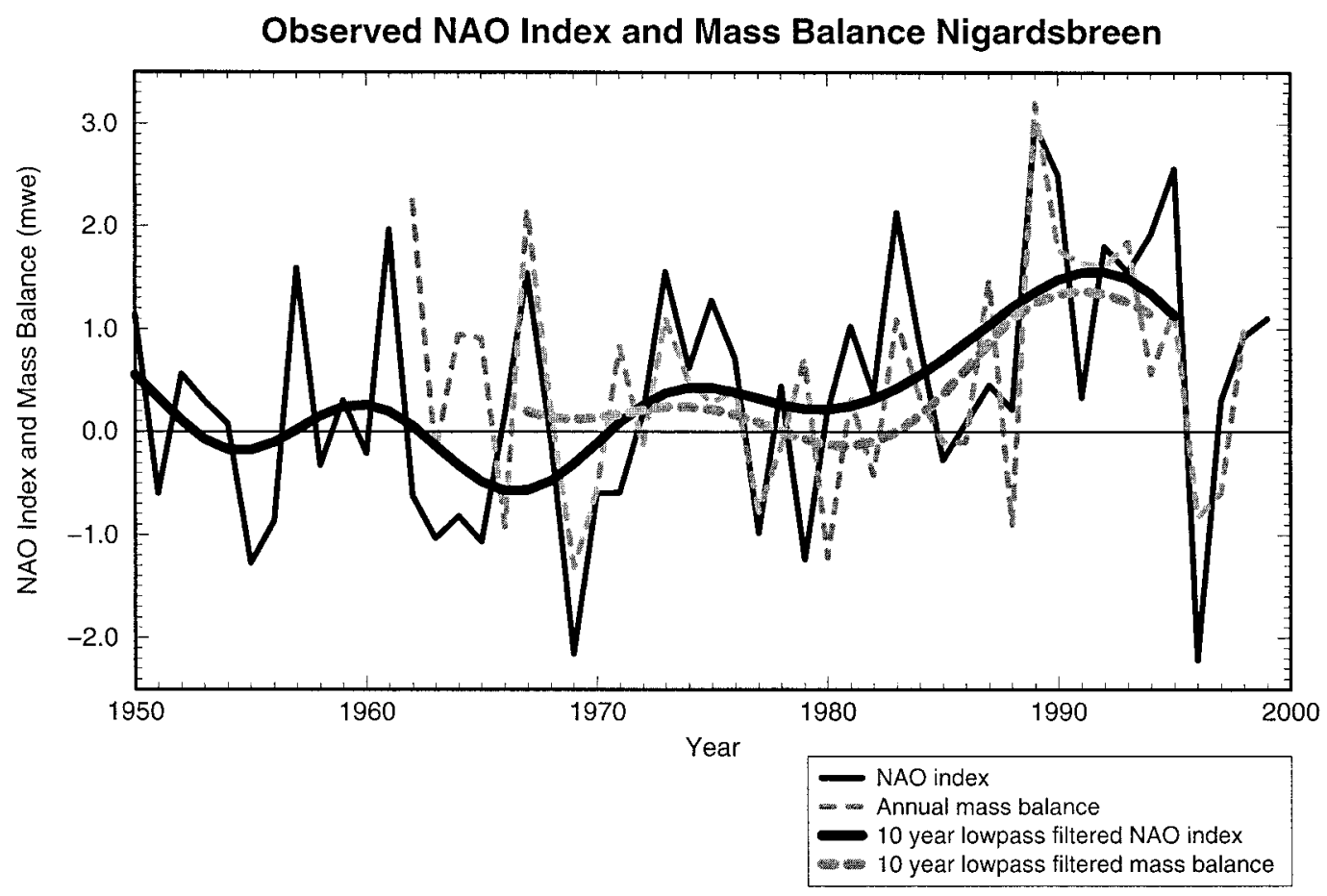

FIG. 13. Observed NAO index for the period 1950-99 (data from Jones et al. 1997; Osborn et al. 1999; solid lines) and observed mass balance for Nigardsbreen 1962-98 (data from IAHS/UNESCO 1998, 1999; dashed lines) along with 10 -yr low-pass-filtered values (heavy lines). The correlation coefficient for annual data is $r=0.58$.

$10 \mathrm{~b}$ and $11 \mathrm{~b})$. Although the precipitation sensitivity of Rhonegletscher is roughly constant throughout the year, the summer precipitation anomaly associated with the $\mathrm{NAO}$ is low and its impact is therefore rather restricted.

\section{2) Seasonal impact of temperature}

Positive anomalies of more than $1^{\circ} \mathrm{C}$ in surface air winter temperature associated with the NAO (Fig. 12b) occur over Scandinavia and other parts of northern Europe extending eastward across much of Eurasia. Negative anomalies can be found over Greenland and parts of the northwest Atlantic.

For the region of Nigardsbreen, we find a considerable winter temperature anomaly of about $2^{\circ} \mathrm{C}$ associated with the NAO. However, the sensitivity of Nigardsbreen to winter temperature changes is low (Fig. $3 \mathrm{a})$; the impact on the annual glacier mass balance is therefore in fact negligible (Fig. 11a). This is also true for Rhonegletscher (Fig. 11b), which experiences only a small winter temperature anomaly associated with the NAO (Fig. 12b). In summer a rather strong impact of temperatures could be expected due to the relatively high sensitivity of the glaciers during this season. However, the simulated temperature anomalies associated with the NAO are low for both glaciers; their overall impact on the annual mass balance therefore still remains smaller when compared with the impact of precipitation.
In summary, it has been shown (concerning the investigated GCM control integrations excluding external forcing) that, for both glaciers, 1) the overall impact of precipitation changes on annual mass balance variations is by far higher than the impact of temperature, and 2) mass balance changes of the glaciers are to a large extent caused by variations in winter precipitation associated with the NAO. A high phase of the NAO means clearly enhanced winter precipitation for the region of Nigardsbreen, typically leading to a higher-than-normal positive mass balance over the year. For Rhonegletscher, a high NAO phase typically means reduced winter precipitation leading to a lower-than-normal mass balance. The opposite is valid for a low phase of the NAO.

\section{Recently observed positive mass balances of Norwegian glaciers}

The net mass balance averaged over available observational data from 32 worldwide glaciers in 10 mountain ranges shows a considerable worldwide glacier mass loss on the order of a few decimeters per year for the period 1980-97 (IAHS/UNESCO 1999; Haeberli et al., 1999). In this global context, strong positive mass balances as observed for Nigardsbreen and other maritime glaciers in southwestern Norway over the same time period may appear to be exceptional. With respect to the results obtained above, it is now interesting to discuss these positive mass balances in more detail. 
It has already been mentioned (section $5 \mathrm{c}$ ) that periods of generally strong positive mass balances, comparable to the observed mass balances for Nigardsbreen within the period 1980-95 (Fig. 13, thin dashed line), appear in the GCM simulations exclusively because of internal climate variations (Fig. 5a). It has been shown that a comparable positive mass balance event has, for example, been simulated by the coupled ECHAM4/ OPYC GCM at around year 50 (denoted as year 340 in Fig. 5a). With respect to the NAO index as presented in Fig. 9 it has now become evident that this simulated event of positive mass balances can clearly be associated with a strong positive phase of the NAO in the model (Fig. 9a, heavy solid line, around year 50).

This is in agreement with observational data illustrated in Fig. 13. The observed annual mass balances for Nigardsbreen within the period 1962-98 (dashed lines) along with the NAO index for the period 195099 (thin solid line) are shown. It is immediately evident that mass balance and NAO index are remarkably well correlated; the correlation coefficient for annual data is $r=0.58$ (95\% significance level at $r \geq 0.29$ ) within the period 1962-98. For the period 1966-98, the correlation coefficient even increases to $r=0.71(95 \%$ significance level for $r \geq 0.30$ ). The 10 -yr low-passfiltered time series (thick lines) indicate that also the decadal trends are comparable for the last three decades.

The investigation of the individual seasonal impact of temperature and precipitation in the GCM experiments (sections 6b-d) showed that this link between mass balance and the NAO is mainly established through winter precipitation variations associated with the NAO exerting a strong impact on the annual mass balance of the glacier.

The GCM experiments and investigation of the forcing factors for glacier mass balance in this study therefore provide evidence for the assumption that generally positive mass balance tendencies as recently observed for Nigardsbreen can be related to enhanced precipitation in winter associated with a positive phase of the NAO. The observed strong positive glacier mass balances within 1980-95 can thus be seen as a consequence of the corresponding observed persistent positive phase of the NAO within this time period. This mechanism is also likely to be valid for other maritime Norwegian glaciers that have also shown strong positive mass balances within this period (IAHS/UNESCO 1999).

\section{Summary and conclusions}

A process-based modeling approach has been applied in order to simulate glacier mass balance records for Nigardsbreen (Norway) and Rhonegletscher (Switzerland) using downscaled GCM experiments.

Statistical downscaling of GCM output is based on the large-scale flow obtained from daily ECMWF reanalyses and local station data in the vicinity of the glaciers. On average, $79 \%$ of variance for observed monthly temperatures in the region of Nigardsbreen and $80 \%$ of variance in the region of Rhonegletscher are explained using reanalyses. For local precipitation, the explained variances are $65 \%$ and $51 \%$, respectively. The composition of large-scale predictors and their individual impact (especially on precipitation) vary considerably for individual stations within the areas of investigation.

The sensitivity of glacier mass balance to local temperature and precipitation is represented by glacier-specific SSCs calculated from a mass balance model of intermediate complexity. The sensitivity of Rhonegletscher to changes in precipitation is almost constant throughout the year, whereas for Nigardsbreen, a change in summer precipitation (mainly falling as rain because of higher annual temperatures at the equilibrium line of the glacier) has only a marginal effect. The sensitivity to changes in summer temperature (when melting occurs) is higher for Nigardsbreen relative to Rhonegletscher. A temperature change in winter has almost no effect on mass balance for both glaciers.

The process-based mass balance modeling approach and the statistical downscaling strategy is validated against observations by simulating glacier mass balance using ECMWF reanalyses. In situ measurements of mass balance for Nigardsbreen are found to agree reasonably well with simulations for the period 1979-93. A considerable impact on mass balance is found when using different stations in the vicinity of the glaciers for downscaling.

Mass balance fluctuations for Nigardsbreen and Rhonegletscher are simulated using multicentury coupled (ECHAM4/OPYC) and mixed-layer (ECHAM4/MLO) GCM integrations excluding external forcings. The experiments show that periods of generally strong positive mass balances comparable to observed mass balances for Nigardsbreen during the 1980s and the first half of the 1990s do appear in the GCM integrations, suggesting that such periods may be explained by internal variations in the climate system. For Nigardsbreen (Rhonegletscher), a high correlation (anticorrelation) between decadal variations in the North Atlantic oscillation and glacier mass balance in the model experiments is found. The correlation coefficients for the relation between the NAO index and mass balance are $r=0.55$ and $r=$ -0.64 for Nigardsbreen and Rhonegletscher, respectively.

The actual impact of temperature (precipitation) as simulated by the downscaled GCM experiments on mass balance variations of the glaciers is defined as the product of glacier sensitivity and one standard deviation of simulated temperature (precipitation) variability for individual months. In the coupled GCM experiment, the overall impact of precipitation changes on glacier mass balance variations is 1.6 times and 3 times higher for Nigardsbreen and Rhonegletscher, respectively, as compared with the impact of temperature. Furthermore, precipitation is the dominant factor for the link between 
mass balance and the NAO. Mass balance changes of the glaciers due to precipitation are to a great extent caused by variations in winter precipitation associated with the NAO. A high phase of the NAO means clearly enhanced winter precipitation for the region of Nigardsbreen, typically leading to a higher-than-normal positive mass balance over the year. For Rhonegletscher, a high NAO phase typically means reduced winter precipitation leading to a lower-than-normal mass balance.

This mechanism, established using multicentury coupled GCM experiments, can explain the observed strong positive mass balances for Nigardsbreen and possibly other maritime Norwegian glaciers within the period 1980-95. It has been shown that observed annual glacier mass balances and the observed NAO index are remarkably well correlated within the period 1962-98. The experiments in this study provide evidence for the assumption that the generally positive mass balance tendencies recently observed for Nigardsbreen can be related to enhanced precipitation in winter associated with a positive phase of the NAO. The observed strong positive glacier mass balances within 1980-95 can thus be seen as a consequence of the corresponding observed persistent positive NAO phase.

Glacier mass balances of Alpine glaciers have been strongly negative during the decade $1980-90$. The average mass balance value has been -0.65 mwe (Haeberli et al. 1999), resulting in an estimated loss of $10 \%-$ $20 \%$ of ice volume since 1980 (Haeberli and Beniston 1998). The results of the present study indicate that this loss of mass balance can (at least as has been demonstrated for Rhonegletscher) partly be explained by the strong positive phase of the NAO within this time period. However, it is of course necessary to account for the general positive temperature trend observed in this region; extremely warm temperatures have affected the Alpine region considerably within 1980-90 (Beniston et al. 1994). Mass balance changes due to precipitation associated with the NAO are in this region therefore superimposed on changes due to the anomalous warm temperatures that occurred in this period. In this context, the method described in this paper may-when applied to transient GCM integrations with increasing greenhouse gases-allow a more precise interpretation of the distinct effect of temperature.

The mass balance records simulated in this study will serve as basis for the simulation of glacier length records using a dynamic ice-flow model. This will enable a comparison between simulated glacier length fluctuations and long observed or reconstructed records of glacier length in order to further investigate natural climate variability as indicated by glaciers (Reichert et al. 2001, unpublished manuscript).

Acknowledgments. The authors would like to thank E. Roeckner, H. Graß1, D. Dommenget, J. Jones, and A. Tompkins for valuable comments and discussions. We thank N. Noreiks for help on graphic representation.
Glacier mass balance data were obtained from the Norges Vassdrags- og Energiverk (NVE) and the World Glacier Monitoring Service (WGMS), the ECMWF provided meteorological reanalyses, and the Swedish Meteorological and Hydrological Institute (SMHI) contributed operational weather station data. The study was supported by the European Commission under Contract ENV4-CT95-0072 and by NOAA/ESH Grant NA86GP0437. The Alexander von Humboldt Foundation is thanked for supporting B. K. Reichert as a Feodor Lynen Fellow. Model simulations were performed at the German Climate Computing Center (DKRZ) in Hamburg, Germany.

\section{REFERENCES}

Bacher, A., J. M. Oberhuber, and E. Roeckner, 1998: ENSO dynamics and seasonal cycle in the tropical Pacific as simulated by the ECHAM4/OPYC3 coupled general circulation model. Climate Dyn., 14, 431-450.

Barnston, A. G., and R. E. Livezey, 1987: Classification, seasonality and persistence of low-frequency circulation patterns. Mon. Wea. Rev., 115, 1083-1126.

Bengtsson, L., and B. K. Reichert, 2000: Global climate change and natural climate variability - what are their reasons? (in German). Energie und Umwelt-Wo liegen optimale Lösungen? S. Wittig and J. Wolfrum, Eds., Union der deutschen Akademien der Wissenschaften und Heidelberger Akademie der Wissenschaften, Springer Verlag, 27-57.

Beniston, M., M. Rebetez, F. Giorgi, and M. R. Marinucci, 1994: Temperature variations during the last century at high elevation sites. Climatic Change, 35, 253-279.

Christoph, M., U. Ulbrich, J. M. Oberhuber, and E. Roeckner, 1999: The role of ocean dynamics for low-frequency fluctuations of the NAO in a coupled ocean-atmosphere GCM. Max-PlanckInstitut für Meteorologie, Rep. 285, 27 pp. [Available from MPI für Meteorologie, Bundesstr. 55, 20146 Hamburg, Germany.]

Cubasch, U., H. von Storch, J. Waszkewitz, and E. Zorita, 1996: Estimates of climate change in southern Europe derived from dynamical climate model output. Climate Res., 7, 129-149.

Gibson, J. K., P. Kållberg, S. Uppala, A. Nomura, A. Hernandez, and E. Serrano, 1997: ERA Description. ECMWF Re-Analysis Project Report Series, Rep. 1, 71 pp. [Available from ECMWF, Shinfield Park, Reading, Berkshire RG2 9AX, United Kingdom.]

Gregory, J. M., and J. Oerlemans, 1998: Simulated future sea-level rise due to glacier melt based on regionally and seasonally resolved temperature changes. Nature, 391, 474-476.

Grötzner, A., M. Latif, and T. P. Barnett, 1998: A decadal climate cycle in the North Atlantic Ocean as simulated by the ECHO coupled GCM. J. Climate, 11, 831-847.

Haeberli, W., 1995: Glacier fluctuations and climate change detection. Geogr. Fis. Din. Quat., 18, 191-199.

__ and M. Beniston, 1998: Climate change and its impacts on glaciers and permafrost in the Alps. Ambio, 27, 258-265.

_, R. Frauenfelder, M. Hoelzle, and M. Maisch, 1999: On rates and acceleration trends of global glacier mass changes. Geogr. Ann., 81A, 585-591.

Hasselmann, K., 1976: Stochastic climate models I: Theory. Tellus, 28, 473-485.

Hoelzle, M., and W. Haeberli, cited 1999: World Glacier Monitoring Service, world glacier inventory. [Available online at nsidc@ kryos.colorado.edu.]

Houghton, J. T., G. J. Jenkins, and J. J. Ephraums, 1990: Climate Change: The IPCC Scientific Assessment. Cambridge University Press, $365 \mathrm{pp}$.

Hurrell, J. W., 1995: Decadal trends in the North Atlantic oscillation: Regional temperatures and precipitation. Science, 269, 676-679. 
1996: Influence of variations in extratropical wintertime teleconnections on Northern Hemisphere temperature. Geophys. Res. Lett., 23, 665-668.

_ with the North Atlantic oscillation. Climatic Change, 36, 301326.

IAHS/UNESCO, 1998: Fluctuations of Glaciers 1990-1995. Vol. VII, World Glacier Monitoring Service, $296 \mathrm{pp}$

__ 1999: Glacier Mass Balance Bulletin. No. 5, W. Haeberli, M. Hoelzle, and R. Frauenfelder, Eds., World Glacier Monitoring Service, $104 \mathrm{pp}$.

Jones, P. D., T. Jonsson, and D. Wheeler, 1997: Extension to the North Atlantic oscillation using early instrumental pressure observations from Gibraltar and south-west Iceland. Int. J. Climatol., 17, 1433-1450.

Kushnir, Y., 1994: Interdecadal variations in the North Atlantic sea surface temperature and associated atmospheric conditions. $J$. Climate, 7, 141-157.

_ , and J. M. Wallace, 1989: Low-frequency variability in the Northern Hemisphere winter: Geographical distribution, structure and time-scale dependence. J. Atmos. Sci., 46, 3122-3141.

Latif, M., and T. P. Barnett, 1994: Causes of decadal climate variability over the North Pacific and North America. Science, 266, 634-637.

Nesje, A., Ø. Lie, and S. O. Dahl, 2000: Is the North Atlantic oscillation reflected in Scandinavian glacier mass balance records? J. Quat. Sci., 15, 587-601.

Oberhuber, J. M., 1993: Simulation of the Atlantic circulation with a coupled sea ice-mixed layer-isopycnal general circulation model. Part I: Model description. J. Phys. Oceanogr., 23, 808829.

Oerlemans, J., 1989: A projection of future sea level. Climatic Change, 15, 151-174.

_ 1992 : Climate sensitivity of glaciers in southern Norway: Application of an energy-balance model to Nigardsbreen, Helstugubreen and Alfotbreen. J. Glaciol., 38, 223-232.

__ 1997: A flow-line model for Nigardsbreen: Projection of future glacier length based on dynamic calibration with the historic record. Ann. Glaciol., 24, 382-389.

— and J. P. F. Fortuin, 1992: Sensitivity of glaciers and small ice caps to greenhouse warming. Science, 258, 115-117.

— meteorological data by using a seasonal sensitivity characteristic. J. Glaciol., 46, 1-6.

Osborn, T. J., K. R. Briffa, S. F. B. Tett, P. D. Jones, and R. M. Trigo, 1999: Evaluation of the North Atlantic oscillation as simulated by a coupled climate model. Climate, Dyn., 15, 685-702.

Østrem, G., K. D. Selvig, and K. Tandberg, 1988: Atlas over breer $i$ S $\phi$-Norge. Norges Vassdrags- og Energiverk, Hydrologisk Avdeling, Meddelelse, Norway, $154 \mathrm{pp}$.

Paterson, W. S. B., 1994: The Physics of Glaciers. 3d ed. Pergamon, $496 \mathrm{pp}$.

Reichert, B. K., 2000: Quantification of natural climate variability in paleoclimatic proxy data using general circulation models: Application to glacier systems. Ph.D. thesis, Max-Planck-Institut für Meteorologie, Examensarbeit 72, 124 pp. [Available from
MPI für Meteorologie, Bundesstr. 55, 20146 Hamburg, Germany.]

__ L. Lengtsson, and O. Åkesson, 1999: A statistical modeling approach for the simulation of local paleoclimatic proxy records using general circulation model output. J. Geophys. Res., 104, 19 071-19083.

Roeckner, E., 1997: Climate sensitivity experiments with the MPI/ ECHAM4 model coupled to a slab ocean (abstract). Euroclivar Workshop on Cloud Feedbacks and Climate Change, C. A. Senior and J. F. B. Mitchell, Eds., Hadley Centre for Climate Prediction and Research, 20 pp.

__ and Coauthors, 1996: The atmospheric general circulation model ECHAM-4: Model description and simulation of present-day climate. Max-Planck-Institut für Meteorologie, Rep. 218, 90 pp. [Available from MPI für Meteorologie, Bundesstr. 55, 20146 Hamburg, Germany.]

_ - L. Bengtsson, J. Feichter, J. Lelieveld, and H. Rodhe, 1999: Transient climate change simulations with a coupled atmosphere-ocean GCM including the tropospheric sulfur cycle. $J$. Climate, 12, 3004-3032.

Rogers, J. C., 1985: Atmospheric circulation changes with the warming over the northern North Atlantic in the 1920s. J. Climate Appl. Meteor., 24, 1303-1310.

Simmons, A. J., D. M. Burridge, M. Jarraud, C. Girard, and W. Wergen, 1989: The ECMWF medium-range prediction models: Development of the numerical formulations and the impact of increased resolution. Meteor. Atmos. Phys., 40, 28-60.

Stendel, M., and E. Roeckner, 1998: Impacts of horizontal resolution on simulated climate statistics in ECHAM4. Max-Planck-Institut für Meteorologie, Rep. 253, 57 pp. [Available from MPI für Meteorologie, Bundesstr. 55, 20146 Hamburg, Germany.]

Sutherland, D. G., 1984: Modern glacier characteristics as a basis for inferring former climates with particular reference to the Loch Lomond Stadial. Quat. Sci. Rev., 3, 291-309.

Timmermann, A., M. Latif, R. Voss, and A. Grötzner, 1998: North Atlantic interdecadal variability: A coupled air-sea mode. J. Climate, 11, 1906-1931.

van Loon, H., and J. C. Rogers, 1978: The seesaw in winter temperatures between Greenland and Northern Europe. Part I. General description. Mon. Wea. Rev., 106, 296-310.

Visbeck, M., and Coauthors, 1998: Atlantic climate variability experiment prospectus. Proc., Workshop Dallas, February 1998 and Workshop Florence, May 1998, Lamont-Doherty Earth Observatory, Columbia University, $49 \mathrm{pp}$. [Available from LamontDoherty Earth Observatory, Columbia University, 61 Route 9W, Palisades, NY, 10964.]

Walker, G. T., and E. W. Bliss, 1932: World weather V. Mem. Roy. Meteor. Soc., 4, 53-84.

Wallace, J. M., and D. S. Gutzler, 1981: Teleconnections in the geopotential height field during the Northern Hemisphere winter. Mon. Wea. Rev., 109, 784-812.

Wigley, T. M. L., and S. C. B. Raper, 1993: Future changes in global mean temperature and sea level. Climate and Sea Level Change: Observations, Projections and Implications, R. A. Warrick, E. M. Barrow, and T. M. L. Wigley, Eds., Cambridge University Press, 111-133. 